\title{
Development of Primary Sludge Control Technology Based on Solids Loading Rate in Sidestream MLE Process
}

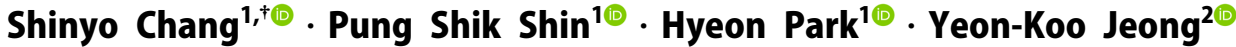 \\ 'Seoul Waterworks Research Institute, Seoul Metropolitan Government \\ ${ }^{2}$ Department of Environmental Engineering, Kumoh National Institute of Technology
}

(Received September 21, 2020; Revised November 3, 2020; Accepted November 23, 2020)

Objectives: By measuring the solids loading rate for the sidestream, it was intended to achieve increased treatment capacity and improved process performance by developing control technologies for primary sludge removal, recirculation, and input.

Methods: The pilot plant was manufactured by the primary clarifier + MLE process similar to the full-scale plant and was configured to control the amount of sludge withdrawal based on the inflow solids loading rate. The state point analysis was used to determine removal underflow withdrawal rate and the total underflow withdrawal rate for the primary sludge. The operation was divided into manual withdrawal, automatic withdrawal, automatic withdrawal + recirculation, and automatic withdrawal + input methods. The performance evaluation items for primary sludge control technology were primary sludge concentration and SS removal efficiency for primary and secondary clarifiers. The improvement in the performance of the bioreactor by recirculation and input was judged through the removal efficiency of ammonium nitrogen, TIN (Total Inorganic Nitrogen) and phosphate phosphorus, SNR (Specific Nitrification Rate), and SDNR (Specific Denitrification Rate). The cause of the performance improvement was analyzed by comparing the acetic acid concentration changed by recirculation and the microbial community characteristics.

Results and Discussion: The average value of SS monitoring of the sidestream influent was $2.2(0.7 \sim 6.3) \mathrm{g} / \mathrm{L}$ and the primary clarifier needed treatment in response to high concentration SS and fluctuations. It is judged that the state point analysis based on the actual settling rate can accurately suggest whether the stable operation of primary sludge removal, recirculation, and input is the possible and specific design and operation standards. The automatic withdrawal that controls the underflow withdrawal rate according to the change of the inflow solids loading rate could stably draw out the high-concentration sludge and maintain the SS removal efficiency. It is believed that stable operation is possible even in the sludge recirculation operation, and the treatment capacity of the primary clarifier can be increased more than two times in a full-scale plant. By recirculation of the primary sludge, the TIN removal efficiency in the bioreactor was improved by $24.2 \sim 52.3 \%$, and the phosphate phosphorus removal efficiency was improved by up to $20.1 \%$. The TIN removal efficiency in the bioreactor was improved by $32.6 \%$ by the input of primary sludge. VFAs (Volatile Fatty Acids) including acetic acid was produced and the removal efficiency was improved because it was in contact with primary sludge by recirculation and the ratio of major fermentation microorganisms was present at $2.0 \%$. It is determined that $26.4 \%$ of the main species of microorganisms treated with nitrogen and phosphorus exist in the sidestream inflow and the removal efficiency was improved by supplying microorganisms through the input of primary sludge.

Conclusions: Technology that controls primary sludge removal, recirculation, and input by measuring the solids loading rate for the sidestream is believed to increase the treatment capacity of the primary clarifier and improve the nitrogen and phosphorus removal efficiency of the bioreactor.

Keywords : Solids Loading Rate, Sidestream, Primary Sludge Recirculation, Automatic Control, Volatile Fatty Acids

The Korean text of this paper can be translated into multiple languages on the website of http:/jksee.or.kr through Google Translator. 


\title{
연구논문
}

\section{반류수 MLE공정에서 고형물 부하율 기반 일차슬러지 제어기술 개발}

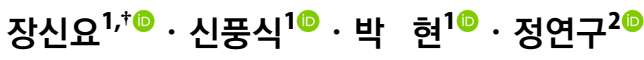 \\ ${ }^{1}$ 서울특별시 서울물연구원 \\ 금오공과대학교 환경공학과
}

목적 : 반류수를 대상으로 고형물 부하율을 측정하여 일차슬러지 제거, 재순환, 투입에 대한 제어기술을 개발하여 처리용량 증가 및 공정성능 향상을 달성하고자 하였다.

방법: 파일럿 플랜트는 실플랜트와 유사하게 일차침전지+MLE공정으로 제작하였고, 유입 고형물 부하율을 기반으 로 슬러지 인발량을 제어할 수 있도록 구성하였다. 상태점 분석으로 일차슬러지에 대한 제거 하부배출속도, 전체 하부배출속도를 결정하였다. 수동인발, 자동인발, 자동인발+재순환, 자동인발+투입 방식으로 구분하여 운전하였다. 일차슬러지 제어기술에 대한 성능평가 항목은 일차, 이차침전지의 SS 제거효율과 일차슬러지 농도로 하였다. 재순 환 및 투입에 의한 생물반응조 성능향상은 암모니성질소, 총무기질소(TIN), 인산염인 제거효율과 SNR, SDNR을 통 해서 판단하였다. 재순환으로 변화된 아세트산 농도와 미생물 군집특성을 비교하여 성능향상 원인을 분석하였다.

결과 및 토의: 유입 반류수 SS 모니터링 평균값은 $2.2(0.7 \sim 6.3) \mathrm{g} / \mathrm{L}$ 로 일차침전지는 고농도 SS와 변동에 대응한 처리가 필요하였다. 실제 침강속도에 기반한 상태점 분석이 정밀하게 일차슬러지 제거, 재순환, 투입에 대한 안정 적인 운전 가능여부와 구체적인 설계 및 운영기준을 제시할 수 있는 것으로 나타났다. 유입 고형물 부하율 변화에 따라서 하부배출속도를 제어하는 자동인발은 고농도 슬러지를 안정적으로 인발할 수 있으며, SS 제거효율도 안정 적으로 유지할 수 있었다. 슬러지 재순환 운전에서도 안정적 운전이 가능하며 실플랜트에서 일차침전지 처리용량을 2 배 이상 증가할 수 있는 것으로 나타났다. 일차슬러지 재순환으로 생물반응조 TIN 제거효율은 $24.2 ~ 52.3 \%$ 향상 되었고 인산염인 제거효율은 최대 $20.1 \%$ 향상되었다. 일차슬러지 투입으로 생물반응조 TIN 제거효율이 $32.6 \%$ 향 상되었다. 아세트산을 포함한 휘발성 유기산이 생성되고 제거효율이 향상된 것은 재순환에 의해 일차슬러지와 접촉하였고 발효 미생물 주요 종 비율이 $2.0 \%$ 존재하였기 때문으로 판단된다. 유입 반류수에는 질소, 인 처리 미생물 주요 종이 $26.4 \%$ 존재하여, 일차슬러지 투입으로 미생물 공급이 이루어져서 제거효율을 향상시켰다고 판단 된다.

결론: 반류수를 대상으로 고형물 부하율을 측정하여 일차슬러지 제거, 재순환, 투입을 제어하는 기술은 일차침전 지 처리용량을 증가시킬 수 있고 생물반응조의 질소, 인 제거효율을 향상시키는 것으로 사료된다.

주제어 : 고형물 부하율, 반류수, 일차슬러지 재순환, 자동제어, 휘발성 유기산

\section{1. 서론}

최근 공공수역에 부영양화로 녹조현상이 자주 발생되고 있으며 주요한 원인물질은 질소, 인 등으로 알려져 있다. 이 를 저감하기 위해 공공하수처리시설 수질기준은 지속적으 로 강화되고 있다. 현재 하수처리시설에서 질소처리가 어려 워 방류수 수질기준을 만족하는데 어려움이 있으며, 생물 학적 인 처리의 한계로 많은 응집제가 사용되고 있다. ${ }^{1,2}$ 최 근에 생물학적 질소, 인 제거효율을 향상시키기 위해 많은 연구가 추진되고 있다.-7) 그 중에서도 슬러지 처리공정에
서 발생한 고농도 반류수를 별도로 처리하여 하수처리공정 (Mainstream)으로 유입되는 질소, 인, SS 등의 부하를 낮추 는 방법이 제안되고 있다. 슬러지 처리공정의 고액분리과정 에서 액상으로 발생하는 반류수는 질소, 인, SS 등 고농도 오염물질을 포함하고 있으며, 소화공정 전 단계에서 발생한 반류수는 질소가 낮고 소화공정을 거친 후의 반류수는 질소 가 높아진다. 하수처리공정에서 인 제거용 응집제 사용량에 따라서 반류수 인 농도는 달라지게 된다. 농축과 탈수공정 에서 고형물 회수율이 낮으면 반류수 SS는 상승하게 된다. 따라서 반류수는 하수 및 슬러지 처리공정의 상태에 따라서 
변하는 질소, 인, $\mathrm{SS}$ 등의 농도에 대응이 필요하다.

우선 슬러지 처리공정에서 고형물 회수율이 낮아 반류수 의 고형물 농도가 상승하여 생물학적 처리공정으로 유입되 면 거품발생과 활성슬러지 분율 감소 등으로 원활한 하수처 리가 이루어지지 못하기 때문에 별도의 반류수처리공정 (Sidestream)이 필요하게 된다. ${ }^{8)}$ 유입 반류수의 $\mathrm{SS}$ 농도가 $2 \mathrm{~g} / \mathrm{L}$ 이상으로 발생된다면 반류수처리공정에서 일차처리 가 중요한 역할을 하게 되며 후속 공정인 생물학적 처리에 유입되는 $\mathrm{SS}$ 는 $0.2 \mathrm{~g} / \mathrm{L}$ 로 유지하는 것이 필요하다. 한편 하 수처리에서 일차침전지는 일차처리 및 생물학적 처리를 위 한 예비처리의 역할을 수행하고, 이차침전지는 활성슬러지 와 처리수를 분리하고 침전한 슬러지의 농축을 주목적으로 한다. ${ }^{9)}$ 고형물 농도가 높고 침강속도가 느린 경우에 고형물 부하율(Solid Loading Rate, SLR)을 고려한 고형물 플럭스 (Solids Flux)와 상태점 분석이 침전지 설계 및 운전에 활용 되었다. ${ }^{10-15)}$ 고형물 플럭스는 침전지 단위면적에 있어 하부 로 이동하는 고형물 질량속도를 의미하고 상태점 분석은 고 형물 플럭스 이론을 한계 고형물 플럭스 운전 조건과 관련 된 $\mathrm{SS}$ 농도와 침전지 운전조건을 평가하는 수단으로 활용 되고 있다. ${ }^{16,17)}$ 고형물 농도가 높은 반류수를 대상으로 하는 일차침전지의 설계 및 운전에서도 고형물 부하율에 대한 고려가 필요한 것으로 판단된다. 하지만 고농도 $\mathrm{SS}$ 를 포함 한 반류수를 대상으로 실시간으로 고형물 부하율을 계측하 여 일차침전지를 운전한 사례는 많지 않은 것으로 파악되 었다.

반류수는 알칼리도와 탄소원이 부족하기 때문에 생물학 적 질소처리가 어렵다. 이를 해결하기 위해서 아질산화 및 아질산-탈질화 공정, 부분 아질산화와 혐기성 암모늄 산화 등이 적용되었는데 이는 필요공기량과 탄소원을 감소시키 는 기술이고 국내외에서 다양한 연구가 진행되고 있다. ${ }^{18-24)}$ $\mathrm{J}$ 물재생센터에 설치되어 있는 반류수 처리시설은 MLE (Modified Ludzack-Ettinger)공정으로 구성되어 있다. 새로 운 기술을 적용하는 것도 검토할 수 있지만 현재 설치되어 있는 시설을 최적화시키는 것도 중요하다. MLE공정으로 반 류수의 질소 제거효율을 향상시키기 위해서는 질산화를 위 한 알칼리도 공급과 탈질을 위한 탄소원 공급이 필요하다. MLE공정에서 충분한 rbCOD (readily biodegradable COD)가 존재해서 기질이 PAOs (Phosphate Accumulating Organisms) 에 의해 흡수가 가능할 때와 저장된 탄소의 산화가 일어날 정도로 충분한 호기성 시간이 있을 때에는 생물학적 질소와 인이 동시에 제거될 수 있다. ${ }^{8)}$ 따라서 반류수 처리 MLE공 정에서 질소, 인의 제거효율을 향상시키기 위해서는 탄소원 공급이 중요한 것으로 판단된다.

슬러지를 대상으로 내부탄소원을 생산하여 생물반응조에 공급함으로써 질소, 인 제거효율을 향상시킨 사례가 다수 보 고되었다. ${ }^{25-28)}$ 최근에는 응집제 투입 일차침전지(Chemically
Enhanced Primary Sedimentation, CEPS)를 통해 후속 생물 학적 처리에 대한 유기 부하를 감소시킬 뿐만 아니라 질소 제거 성능을 향상시키는 방법이 소개되었다. ${ }^{29,30)}$ 알루미늄 및 철 계열 응집제를 사용하여 휘발성 유기산(VFAs, Volatile Fatty Acids)을 생산한 사례와 $\mathrm{Fe}$-슬러지가 Al-슬러지보다 가수분해 및 산생성 과정에서 휘발성 유기산을 많이 생산한 다고 보고하였다. ${ }^{31-34)}$ 하지만 별도의 반응기를 통해 슬러지 를 발효시켜 분해가 쉬운 유기물을 공급하는 방법은 설비구 성이 복잡하다는 단점이 있다. 반면 별도의 반응기 없이 일 차슬러지를 침전지로 재순환하는 활성 일차침전지(Activated Primary Sedimentation Tank, APST)를 이용하여 생물반응조 에 탄소원을 공급하는 방법이 있다. 활성 일차첨전지에서 슬러지 계면이 증가하고 재순환 유량이 높을수록 휘발성 유 기산 생산도 증가한다. ${ }^{35)}$ 기계적 교반, 침강 구역의 전단에 배플 설치를 통해 입자들 사이의 충돌 및 마찰 가능성을 증 가시켜 하수의 용존 COD 및 VFAs가 증가되고 후속 생물학 적 질소 및 인 제거의 효율을 개선시킨 사례도 있다. ${ }^{36-38)}$ 활 성 일차첨전지에서 높은 일차슬러지의 재순환 유량은 일차 처리수의 휘발성 유기산 농도를 증가시키지만 침전 효율이 약간 감소한다고 하였다. ${ }^{39)}$ 따라서 재순환이 있는 활성 일차 침전지 적용 시 고형물 부하율 변화에 대한 제어기술이 필 요할 것으로 예상된다.

이에 본 연구에서는 파일럿 플랜트를 이용해 반류수 처리 시설(MLE공정)의 일차침전지 제어기술을 고형물 부하율에 기반하여 개발하고, 이를 실플랜트에 적용하여 제거효율 및 처리용량을 향상시키고자 하였다. 우선 일차침전지 고형물 부하율을 모니터링하고 고형물 플럭스와 상태점 분석을 통 해 하부배출속도를 산정하여, 슬러지 제거, 재순환, 생물반 응조 투입에 대한 제어기술을 개발하고자 하였다. 제어기술 에 대한 성능평가는 $\mathrm{SS}$ 제거효율과 일차슬러지 농도로 하 였다. 일차슬러지를 재순환하는 방법과 생물반응조에 일차 슬러지를 투입하는 방법의 효과는 생물반응조의 질소, 인 제거효율, 일차처리수 성상 변화, 유입수 및 호기조 미생물 군집분석으로 평가하였다.

\section{2. 실험방법}

\section{1. 파일럿 플랜트}

본 연구에서 사용한 반류수 처리 파일럿 플랜트는 원수 공급설비, 일차침전지, 무산소조, 호기조, 이차침전지로 구성하여 $\mathrm{J}$ 물재생센터 반류수 처리시설과 유사한 공정으로 2 세트를 제작하였다(Fig. 1). 원수 공급설비는 MLE 실플랜 트에 유입되는 원수를 파일럿 원수 저장조까지 이송하여 일 차침전지에 일정량을 유입시키는 부분이다. 생물반응조는 교반기로 혼합하여 공기를 공급하지 않는 무산소조와 공기 를 공급하는 호기조로 구성하였으며, 각각은 3 개의 반응조 


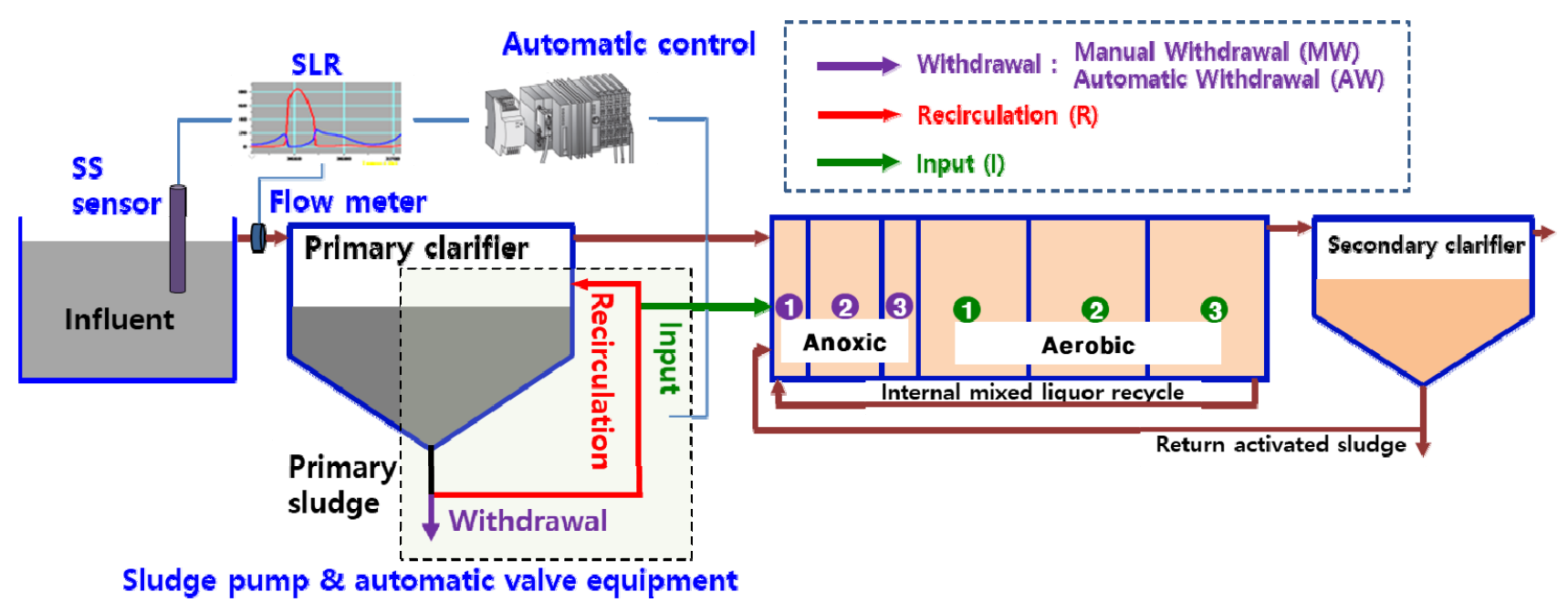

Fig. 1. Schematic diagram of the pilot-scale MLE process with primary sludge control technology.

Table 1. Designed hydraulic retention time (h) of the pilot plant and full-scale MLE process in J WWTP.

\begin{tabular}{cccccc} 
Plants & Primary clarifier & & Anoxic basin & Aerobic basin & Secondary clarifier \\
Pilot 1 & 2.9 & & 5.4 & 16.2 & 12.1 \\
\hline Pilot 2 & 7.4 & & & \\
Full-scale & & & & \\
\hline
\end{tabular}

로 이루어져 있다. 원수 공급펌프, 일차슬러지 인발펌프, 내 부 반송펌프, 외부 반송펌프, 송풍기 등은 인버터로 유량 및 공기공급량 제어가 가능하도록 하였다. SS 측정기는 원수 저장조에 설치하였고, 유입 유량은 원수 저장조에서 일차침 전지로 이송되는 배관에서 측정하였다. 측정된 유입 $\mathrm{SS}$, 유 량 등으로 일차침전지 유입 고형물 부하율을 30 분 단위로 계산하고, 이를 기준으로 슬러지 제거량, 재순환량, 투입량 을 결정하였다. SS 측정기(Hach SC 200 Suspended Solids) 센서는 LED 광원에서 투과된 빛의 $90^{\circ}$ 산란광을 감지하여 $\mathrm{SS}$ 를 측정하고 30 분 간격으로 와이퍼에 의해 자동 세정되 었다. 유입수 SS 연속 모니터링 값은 실험실 측정값과 비교 하여 주 1 회씩 보정하였다.

파일럿과 실플랜트의 설계 체류시간을 Table 1에 정리하 였다. 파일럿 2는 실플랜트와 동일한 설계 체류시간을 갖고 파일럿 1,2 의 생물학적 처리공정은 서로 동일한 크기로 제 작하였으나, 일차침전지는 각각 직경 $0.5 \mathrm{~m}, 0.8 \mathrm{~m}$ 로 하여 체류시간을 다르게 하였다. 일차침전지의 체적은 파일럿 2 가 파일럿 1 보다 2.5 배 컸다.

\section{2. 유입 고형물 부하율에 의한 일차슬러지하부배출속도 산정}

유입 반류수 SS 농도에 따른 침강속도는 $2 \mathrm{~L}$ 실린더(직경 $9.3 \mathrm{~cm}$, 높이 $46 \mathrm{~cm}$ )를 사용하여 측정하였다. SS 농도별 침 강속도 측정값을 침강속도모델로 근사하여 농도와 침강속도 의 관계식을 만들고, 농도와 침강속도 곱으로 중력 고형물 플럭스(Gravity Solids Flux, $\mathrm{SF}_{\mathrm{g}}$ ) 그래프를 작도하였다. 상태
점 분석으로 침전지 운전조건을 평가하기 위해 중력 고형물 플럭스, 월류 고형물 플럭스 운전선(Overflow rate operating line), 하부배출 고형물 플럭스 운전선(Underflow rate operating line)을 작도하였다. 월류 고형물 플럭스 운전선 기울기는 표면 월류율(Surface Overflow Rate, SOR)을 의미하는데 파 일럿에서 운전된 값을 사용하였다. 하부배출 고형물 플럭스 운전선 기울기는 하부배출속도를 의미하고 중력 고형물 플 럭스 곡선을 넘어서지 않도록 하부배출속도를 결정하였다. 파일럿 일차슬러지 배관에서 막힘 없이 원활하게 운전할 수 있는 농도인 $19 \mathrm{~g} / \mathrm{L}$ 를 목표 침전슬러지 농도로 정하였다. 유입 SS $0 \sim 6 \mathrm{~g} / \mathrm{L}$ 범위에서 하부배출속도와 월류 고형물 플럭스를 계산하였다. 일차슬러지 재순환 운전에서는 재순 환되는 슬러지 농도 $19 \mathrm{~g} / \mathrm{L}$ 와 유입 $\mathrm{SS}$ 로 총 SS 농도를 산정 하여 하부배출속도를 결정하였다. 계산된 하부배출속도에 따라서 슬러지 인발량이 결정되고 인발되는 종류에 따라서 제거, 재순환, 투입 하부배출속도로 구분하였다. 2 가지의 하 수배출속도가 존재하는 경우에는 합계를 전체 하부배출속 도로 정하였다.

\section{3. 고형물 부하율 기반 일차슬러지 제어기술 성능평가}

반류수 처리 파일럿 플랜트의 운전은 일차침전지 운전조 건에 따라서 A, B, C, D, E로 구분하였다(Table 2). A는 유입 SS 최대값을 기준으로 슬러지 인발량을 일정하게 유지하는 수동인발(Manual withdrawal, MW) 방식으로 운전하였고, 인 발농도와 처리효율을 파악하여 3 7일 단위로 인발량을 조 
Table 2. Operating conditions of primary sedimentation and bioreactor by experiment period.

\begin{tabular}{|c|c|c|c|}
\hline Classification (Period) & Pilot & Primary sedimentation & Bioreactor \\
\hline A (2018. 6. - 8.) & 1,2 & Manual Withdrawal (MW) & \\
\hline B (2018. 8. - 10.) & 1,2 & Automatic Withdrawal (AW) & \\
\hline$C(2018.10 .-11)$. & 1,2 & Automatic Withdrawal (AW) + Recirculation (R) & \multirow{4}{*}{$\begin{array}{l}\text { Verification of } \\
\text { recirculation and input } \\
\text { effect }\end{array}$} \\
\hline \multirow{2}{*}{ D (2018. 12.) } & 1 & Automatic Withdrawal (AW) + Input (I) & \\
\hline & 2 & Automatic Withdrawal (AW) + Recirculation (R) & \\
\hline E (2019.1.) & 1,2 & Manual Withdrawal (MW) & \\
\hline
\end{tabular}

Table 3. Detailed operation conditions of the aerobic basin according to experimental purpose.

\begin{tabular}{|c|c|c|c|c|c|}
\hline \multirow{2}{*}{ Pilot } & \multirow{2}{*}{ Classification } & \multicolumn{4}{|c|}{ Aerobic 3 basin } \\
\hline & & Temperature $\left({ }^{\circ} \mathrm{C}\right)$ & DO (mg/L) & $\mathrm{pH}$ & MLSS (mg/L) \\
\hline \multirow{3}{*}{1} & C & $21.4(18.5-24.7)$ & $2.3(0.2-7.1)$ & $5.6(4.3-7.4)$ & $2,869(1,414-8,154)$ \\
\hline & $\mathrm{D}$ & $17.0(15.4-17.8)$ & $1.6(0.2-2.9)$ & $6.0(4.9-7.3)$ & $2,597(2,216-2,652)$ \\
\hline & $E$ & $15.7(14.9-16.3)$ & $1.5(0.2-4.8)$ & $6.4(4.4-7.6)$ & $9,999(6,768-11,174)$ \\
\hline \multirow{3}{*}{2} & C & $21.5(18.5-25.1)$ & $2.2(0.2-6.6)$ & $5.7(4.9-7.0)$ & $2,992(884-9,024)$ \\
\hline & $D$ & $16.9(15.4-17.8)$ & $1.8(0.2-2.9)$ & $5.6(4.8-7.0)$ & $8,817(3,954-9,678)$ \\
\hline & $E$ & $16.0(15.5-16.3)$ & $2.1(0.4-4.8)$ & $5.5(4.4-6.3)$ & $7,539(5,136-10,962)$ \\
\hline
\end{tabular}

절하였다. $\mathrm{B}$ 는 유입 고형물 부하율을 기반으로 슬러지 인발 량을 30 분 단위로 결정하는 자동인발(Automatic withdrawal, $\mathrm{AW})$ 방식으로 운전하였다. C는 자동인발 방식을 유지하면 서 일차슬러지 중 일부를 일차침전지로 재순환(Recirculation, $\mathrm{R})$ 하는 자동인발+재순환(AW+R)방식으로 운전하였다. D에서 파일럿 1은 자동인발 방식을 유지하면서 일차슬러지 중 일부 를 생물반응조로 투입(Input, I)하는 자동인발+투입(AW+I) 방식으로 운전하였고, 파일럿 2는 자동인발+재순환(AW+R) 방식으로 운전하였다. $\mathrm{E}$ 는 $\mathrm{A}$ 와 동일하게 수동인발(MW) 방 식으로 운전하였다.

일차슬러지 제어기술에 대한 성능평가 항목은 일차, 이차 $\mathrm{SS}$ 제거효율과 일차슬러지 농도로 하였으며, 각각의 농도는 일주일에 3회씩 분석하였다. C에서 인발시간 동안 일차슬 러지 농도변화를 확인하여 용량이 다른 파일럿 1,2 에서 슬 러지 농도가 일정하게 유지되는 정도를 확인하였다. 일차침 전지에서 운전된 체류시간은 파일럿 1,2 가 실플랜트보다 5.3 배, 2 배 감소하여 운전하였으며, 이는 개발된 일차슬러지 제어기술을 적용하면 처리용량을 증대시킬 수 있는지 여부 를 조사하기 위함이었다.

\section{4. 일차슬러지 재순환/투입에 의한 생물반응조 질소, 인 제거효율}

$\mathrm{C}, \mathrm{D}, \mathrm{E}$ 에서는 일차슬러지 재순환과 생물반응조 투입 효과 를 생물반응조 질소, 인 제거효율 변화를 통하여 검증하고자 하였다(Table 2). A, B는 생물반응조에 메탄올이 투입되어 비 교대상에서 제외하였다. C, D, E에서 파일럿 1 호기조(basin 3) 온도는 각각 $21.4^{\circ} \mathrm{C}, 17.0^{\circ} \mathrm{C}, 15.7^{\circ} \mathrm{C}$ 이었고, 파일럿 2 는 $21.5^{\circ} \mathrm{C}$, $16.9^{\circ} \mathrm{C}, 16.0^{\circ} \mathrm{C}$ 이었다(Table 3). 같은 겨울철기간 $\mathrm{D}, \mathrm{E}$ 를 비교 하여 재순환과 투입효과를 조사하고자 하였다. 평균 MLSS 는 파일럿 1 의 $\mathrm{C}, \mathrm{D}$ 와 파일럿 2의 $\mathrm{C}$ 가 $2,597 \sim 2,992 \mathrm{mg} / \mathrm{L}$ 로 유지되었고, 파일럿 1의 $\mathrm{E}$ 와 파일럿 2의 D, E가 7,539 9,999 $\mathrm{mg} / \mathrm{L}$ 로 유지되었다. 유입수, 일차처리수, 이차처리수, 일차슬 러지 등 각 처리공정의 암모니아성질소, 총무기질소, 인산염 인, 아세트산과 호기조의 온도, $\mathrm{DO}, \mathrm{pH}, \mathrm{MLSS}$ 를 일주일에 3회 씩 분석하였다. 암모니아성질소, 총무기질소(Total Inorganic Nitrogen, TIN), 인산염인, 아세트산은 이온크로마토그래피 (ICS-5000 Ion Chromatography, Dionex)를 이용하였고, 온도, $\mathrm{DO}, \mathrm{pH}$ 는 휴대용 측정기(Multiparameter Instrument, YSI 556 $\mathrm{MPS}$ )를 이용하여 분석하였다. 재순환으로 발생한 일차처리수 성상변화는 아세트산/총무기질소 비, 아세트산/인산염인 비 와 일차슬러지의 아세트산 농도로 조사하였다. 아세트산 생 성 농도는 유입수와 일차처리수의 농도 차이로 판단하였다. 암 모니아성질소, 총무기질소, 인산염인 제거효율과 SNR (Specific Nitrification Rate), SDNR (Specific Denitrification Rate)을 통해 서 일차슬러지 재순환/투입 효과를 판단하였다. 유입 반류수 와 실플랜트 MLE 호기조의 미생물 군집특성을 비교하였다. 채수는 6월, 7월, 8월 9월에 걸쳐 총 4회 분석하였다. 군집분석 순서는 채수, 전처리, 유전자추출, 차세대염기서열분석, 결과 분석으로 하였다. 추출된 유전자는 세균의 $16 \mathrm{~S} \mathrm{V3-V4} \mathrm{region}$ $(2 \times 250 \mathrm{bp})$ 염기서열을 기반으로 한 차세대염기서열분석을 실시하였고 장비는 Illumina Miseq이었다. 사용한 프라이머 (primer)는 341F(CCTACGGGNGGCWGCAG) 및 805R(GAC TACHVGGGTATCTAATCC)이었다. 결과분석은 BIOiPLUG 및 CLcommunity 소프트웨어를 사용하였다. 


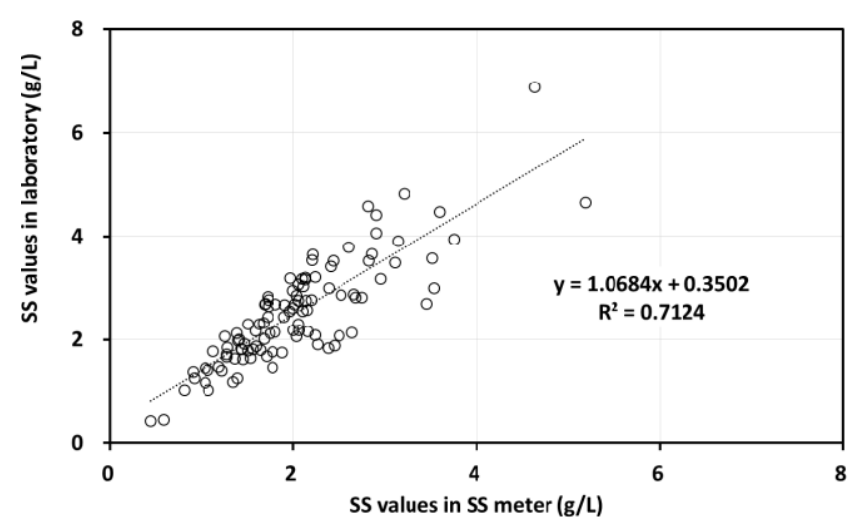

(a) Comparison of SS values measured in SS meter and lab

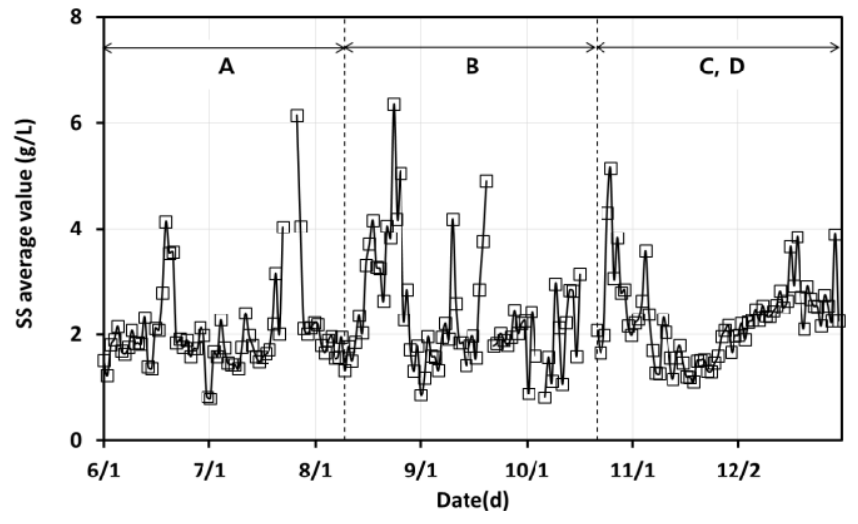

(b) Daily mean concentration of SS

Fig. 2. The influent SS as monitored by the SS meter.

Table 4. Detailed operating conditions of primary sedimentation basins in pilot plant.

\begin{tabular}{|c|c|c|}
\hline Parameters & Pilot 1 & Pilot 2 \\
\hline Influent SS (g/L) & \multicolumn{2}{|c|}{$2.2(0.7-6.3)$} \\
\hline Inflow $\left(\mathrm{m}^{3} / \mathrm{d}\right)$ & $4.03(3.01-5.75)$ & $3.98(3.01-5.90)$ \\
\hline $\operatorname{SOR}\left(\mathrm{m}^{3} / \mathrm{m}^{2} / \mathrm{hr}\right)$ & $0.85(0.63-1.22)$ & $0.33(0.25-0.49)$ \\
\hline Influent SLR ( $\left.\mathrm{kg} / \mathrm{m}^{2} / \mathrm{hr}\right)$ & $1.87(0.77-5.48)$ & $0.73(0.35-2.59)$ \\
\hline Total SLR during recirculation $\left(\mathrm{kg} / \mathrm{m}^{2} / \mathrm{hr}\right)$ & $4.69(0.91-12.26)$ & $1.70(0.35-4.46)$ \\
\hline
\end{tabular}

\section{3. 결과 및 고찰}

\section{1. 유입 고형물 부하율에 의한 일차슬러지 하부배출속도 산정}

\subsection{1. 유입 고형물 부하율 모니터링과 설계기준 비교}

실험실 측정값 $\mathrm{SS}$ 평균은 $2.5(0.4 \sim 6.8) \mathrm{g} / \mathrm{L}$, 시료 채취 시 기에 측정기 $\mathrm{SS}$ 는 $2.0(0.4 \sim 5.1) \mathrm{g} / \mathrm{L}$ 이었으며, 두 측정값의 결정계수는 0.7124 로 측정기는 유입수 SS 변화 경향을 나 타낼 수 있는 것으로 판단하였다(Fig. 2(a)). $\mathrm{A}, \mathrm{B}, \mathrm{C}+\mathrm{D}$ 에 유입 SS 평균은 $2.0 \mathrm{~g} / \mathrm{L}, 2.3 \mathrm{~g} / \mathrm{L}, 2.2 \mathrm{~g} / \mathrm{L}$ 로 각 운전기간에 유입 SS는 비슷하였다(Fig. 2(b)). 측정기 SS 일평균값은 2.2 $(0.7 \sim 6.3) \mathrm{g} / \mathrm{L}$ 이었고 최대값과 최소값의 비는 8.1로 유입수 $\mathrm{SS}$ 의 변화가 크게 나타났고, 반류수 일차침전지는 고농도 $\mathrm{SS}$ 를 처리하는 기능과 변동에 대한 대응이 필요한 것으로 판단되었다. 일반적인 하수처리에서 일차침전지로 유입되 는 $\mathrm{SS}$ 는 $0.2 \mathrm{~g} / \mathrm{L}$ 정도이고, 이차침전지로 유입되는 활성슬 러지 농도는 2 6 g/L, 중력식 농축조로 유입되는 이차슬러 지 농도는 4 12 g/L이었다. ${ }^{899}$ 슬러지 농도로 볼 때 하수처 리공정(Mainstream) 이차침전지가 반류수 일차침전지와 유 사하였다.

표면 월류율(SOR) 설계기준은 하수처리에서 일차, 이차 침전지는 각각 $1.2 \sim 2.0 \mathrm{~m}^{3} / \mathrm{m}^{2} / \mathrm{hr}, 0.6 \sim 1.2 \mathrm{~m}^{3} / \mathrm{m}^{2} / \mathrm{hr}$ 이었고, 일차와 이차슬러지를 대상으로 하는 중력식 농축조는 0.6 $1.4 \mathrm{~m}^{3} / \mathrm{m}^{2} / \mathrm{hr}$ 이었다. ${ }^{8,40)}$ 고형물 부하율 설계기준은 이차침 전지에서 $1.6 \sim 5.2 \mathrm{~kg} / \mathrm{m}^{2} / \mathrm{hr}$ 이고 중력식 농축조에서 $0.8 \sim$ $5.1 \mathrm{~kg} / \mathrm{m}^{2} / \mathrm{hr}$ 이었다. ${ }^{941)}$ 여기서는 유입 반류수 농도가 유사
한 하수처리 이차침전지의 설계기준 최대값과 비교하였다. 실제로 운전된 파일럿 1,2 의 표면 월류율은 각각 $0.85(0.63$ $\sim 1.22) \mathrm{m}^{3} / \mathrm{m}^{2} / \mathrm{hr}, 0.33(0.25 \sim 0.49) \mathrm{m}^{3} / \mathrm{m}^{2} / \mathrm{hr}$ 으로 이차침전 지 설계기준 최대값 $1.2 \mathrm{~m}^{3} / \mathrm{m}^{2} / \mathrm{hr}$ 와 비교하여 파일럿 1 의 최 대값이 $0.02 \mathrm{~m}^{3} / \mathrm{m}^{2} / \mathrm{hr}$ 높았다(Table4). 파일럿 1, 2의 유입 고 형물 부하율은 $1.87(0.77 \sim 5.48) \mathrm{kg} / \mathrm{m}^{2} / \mathrm{hr}, 0.73(0.35 \sim 2.59)$ $\mathrm{kg} / \mathrm{m}^{2} / \mathrm{hr}$ 로 이차침전지 설계기준 최대값 $5.2 \mathrm{~kg} / \mathrm{m}^{2} / \mathrm{hr}$ 와 비 교하여 파일럿 1 최대값이 $0.28 \mathrm{~kg} / \mathrm{m}^{2} / \mathrm{hr}$ 높았다. 파일럿 1 의 $\mathrm{C}$ 와 파일럿 2 의 $\mathrm{C}+\mathrm{D}$ 에서 재순환을 고려한 총 고형물 부 하율은 각각 $4.69(0.91 \sim 12.26) \mathrm{kg} / \mathrm{m}^{2} / \mathrm{hr}, 1.70(0.35 \sim 4.46)$ $\mathrm{kg} / \mathrm{m}^{2} / \mathrm{hr}$ 이었다. 파일럿 1 은 최대값은 이차침전지 설계기 준 최대보다 $7.06 \mathrm{~kg} / \mathrm{m}^{2} / \mathrm{hr}$ 높았다. 파일럿 2 의 경우 일차 침전지 설계용량 대비 유입유량을 실플랜트보다 2 배 증가 시켰음에도 불구하고 이차침전지 설계기준 최대값을 만족 하였다. 실플랜트는 최대 고형물 부하율을 기준으로 설계되 고 운전하기 때문에 처리용량에 여유가 있는 것으로 판단되 었다.

\subsection{2. 상태점 분석에 의한 일차슬러지 하부배출속도 산정}

유입 반류수 농도가 $2.0 \sim 4.7 \mathrm{~g} / \mathrm{L}$ 인 시료의 침강속도는 각 각 $1.9 \sim 4.0 \mathrm{~m} / \mathrm{hr}$ 이었다. 농도와 침강속도를 나타내는 여러 관 계식 중에서 Vesilind에 의해 제안된 함수식을 적용하였다. ${ }^{41}$ 회귀식을 도출한 결과 $\mathrm{y}=6.6132 \mathrm{e}^{-0.241 \mathrm{x}}$ 로 나타내었고, 농도 와 침강속도 곱으로 중력 고형물 플럭스 $\left(\mathrm{SF}_{\mathrm{g}}\right)$ 를 Fig. 3(a)와 같이 나타내었다. 


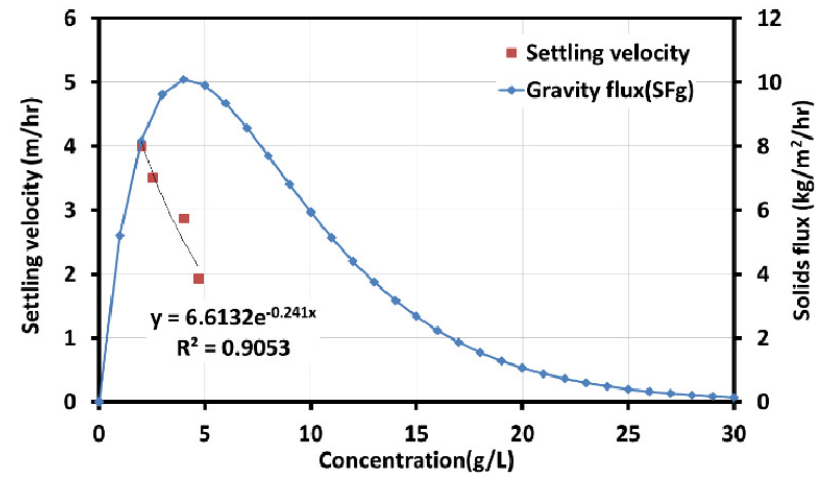

(a) Settling velocity and gravity solids flux

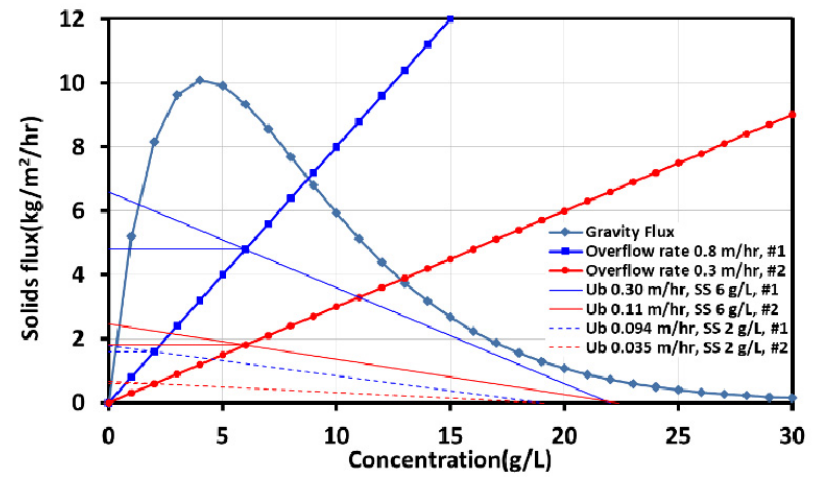

(b) State point analysis

Fig. 3. Primary sludge underflow rate calculation procedure through state point analysis.

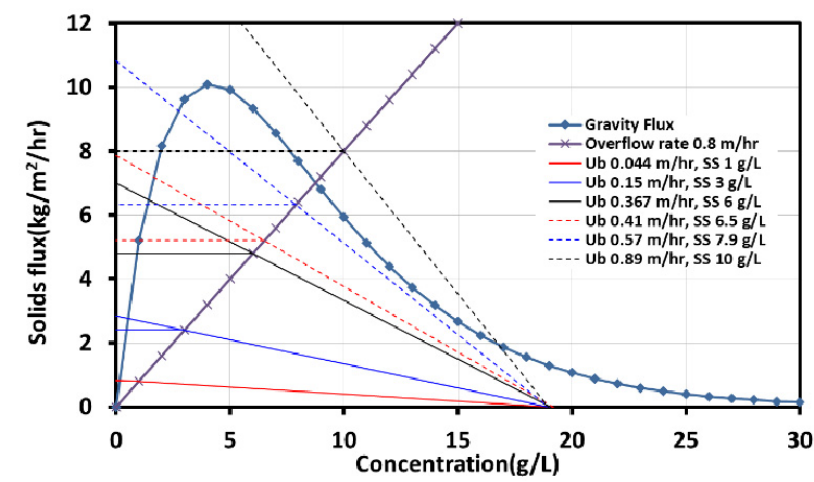

(a) Pilot 1

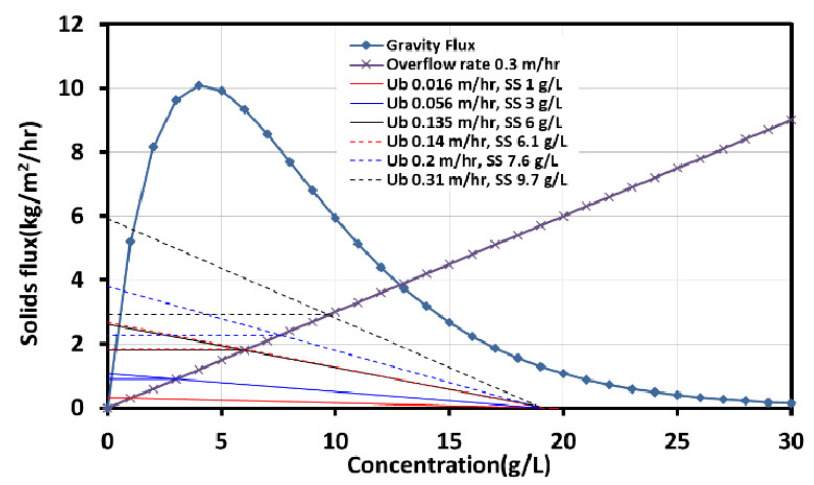

(b) Pilot 2

Fig.4. Calculation of the primary sludge underflow rate considering recirculation.

상태점 분석을 위해 중력 고형물 플럭스(Gravity Solids Flux, $\mathrm{SF}_{\mathrm{g}}$ ), 월류 고형물 플럭스 운전선(Overflow rate operating line), 하부배출 고형물 플럭스 운전선(Underflow rate operating line) 을 Fig.3(b)와 같이 나타내었다. 월류 고형물 플럭스 운전선 기울기는 파일럿 1,2 의 표면 월류율 평균값 $0.8 \mathrm{~m} / \mathrm{hr}, 0.3$ $\mathrm{m} / \mathrm{hr}$ 로 나타내었다. 유입 SS $2 \mathrm{~g} / \mathrm{L}$, 목표 일차슬러지 농도 $19 \mathrm{~g} / \mathrm{L}$ 일 때 하부배출 고형물 플럭스 운전선 기울기(Ub)는 파일럿 1,2 에서 각각 $0.094 \mathrm{~m} / \mathrm{hr}, 0.035 \mathrm{~m} / \mathrm{hr}$ 이었다. 유입 SS $6 \mathrm{~g} / \mathrm{L}$, 목표 일차슬러지 농도 $22 \mathrm{~g} / \mathrm{L}$ 로 하였을 때 하부 배출 고형물 플럭스 운전선 기울기(Ub)는 파일럿 1,2 에서 각각 $0.3 \mathrm{~m} / \mathrm{hr}, 0.11 \mathrm{~m} / \mathrm{hr}$ 이었다. 유입 SS $6 \mathrm{~g} / \mathrm{L}$ 에서 파일럿 1 의 하부배출 고형물 플럭스 운전선은 중력 고형물 플럭스 곡선에 근처에 있고, 곡선을 넘어서면 슬러지가 월류하는 상태로 운전이 불가능하게 될 수도 있다. 상태점 분석은 유 입 SS 농도가 증가함에 따라서 중력 고형물 플럭스 곡선을 넘지 않도록 하면서, 목표 침전슬러지 농도를 달성하기 위 해 하부배출속도를 결정하는 도구로 활용될 수 있다.

목표 일차슬러지 농도를 $19 \mathrm{~g} / \mathrm{L}$ 로 하고 유입 SS $1 \sim 6 \mathrm{~g} / \mathrm{L}$ 로 하였을 때 파일럿 1 인발 하부배출속도는 $0.044 \sim 0.367$ $\mathrm{m} / \mathrm{hr}$ 이었고 파일럿 2는 $0.016 \sim 0.135 \mathrm{~m} / \mathrm{hr}$ 이었다(Fig. 4). 월 류 고형물 플럭스는 파일럿 1 에서 $0.8 \sim 4.8 \mathrm{~kg} / \mathrm{m}^{2} / \mathrm{hr}$ 이었고
파일럿 2에서 $0.3 \sim 1.8 \mathrm{~kg} / \mathrm{m}^{2} / \mathrm{hr}$ 이었다. 슬러지 제거만 있는 일차침전지는 유입 SS $6 \mathrm{~g} / \mathrm{L}$ 에서 하부배출 고형물 플럭스 운전선이 중력 고형물 곡선 안에 있어 안정적 운전이 가능 하였다. 설계기준에 의한 비교에서는 파일럿 1 최대값에서 운전이 어려운데 반해 상태점 분석에서는 안정적인 운전이 가능하여 결과가 달랐다. 고형물 플럭스 이론에 근거한 상 태점 분석은 실제 침강속도로 분석하였기 때문으로 판단되 었다.

목표 일차슬러지 농도 $19 \mathrm{~g} / \mathrm{L}$ 하고 유입 SS가 $1 \sim 6 \mathrm{~g} / \mathrm{L}$ 범 위에서 파일럿 1은 재순환 하부배출속도가 $0.36 \mathrm{~m} / \mathrm{hr}$ (재순 환율 $45 \%$ )일 때 혼합된 SS는 $6.5 \sim 10.0 \mathrm{~g} / \mathrm{L}$ 가 되고, 파일럿 2 는 재순환 하부배출속도가 $0.12 \mathrm{~m} / \mathrm{hr}$ (재순환율 $40 \%$ )일 때 혼합된 SS는 6.1 9.7 g/L가 된다. 파일럿 1에서 인발 하부 배출속도는 $0.41 \sim 0.89 \mathrm{~m} / \mathrm{hr}$ 이고, 파일럿 2에서 $0.14 \sim 0.31$ $\mathrm{m} / \mathrm{hr}$ 이었다. 파일럿 1 의 재순환 운전은 유입 SS $6 \mathrm{~g} / \mathrm{L}$ 에서 중력 고형물 곡선을 벗어났고, $\mathrm{SS} 3 \mathrm{~g} / \mathrm{L}$ (고형물 플럭스 2.4 $\mathrm{kg} / \mathrm{m}^{2} / \mathrm{hr}$ )까지는 안정적 운전이 가능한 것으로 나타났다. 파 일럿 2는 중력 고형물 곡선 안에 있어 재순환 운전이 안정 적으로 가능함을 알 수 있다. 상태점 분석으로 슬러지 재순 환 운전에 대한 안정적 운전 가능여부와 구체적인 설계 및 운영기준을 제시할 수 있었다. 


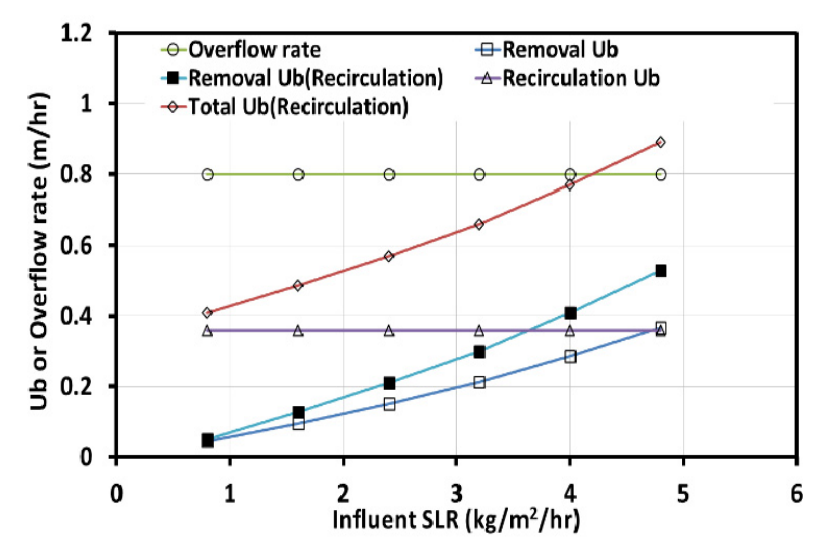

(a) Pilot 1

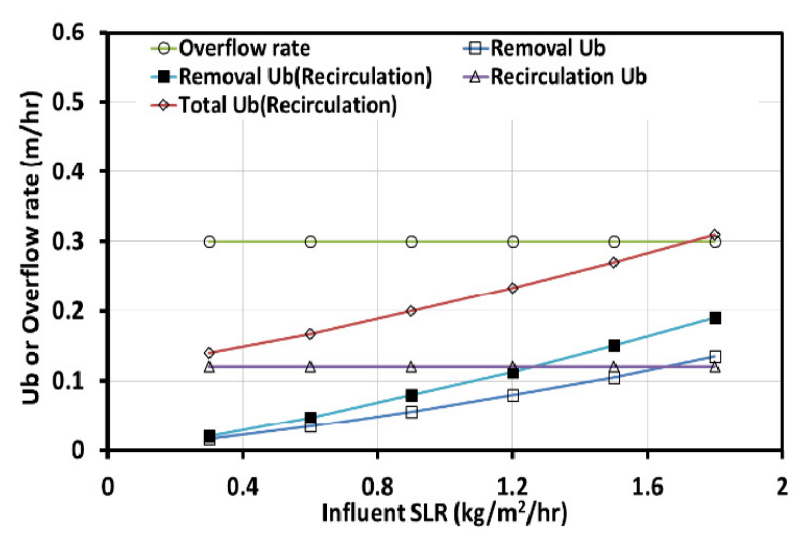

(b) Pilot 2

Fig. 5. Underflow rate of primary sludge calculated based on influent solids loading rate.

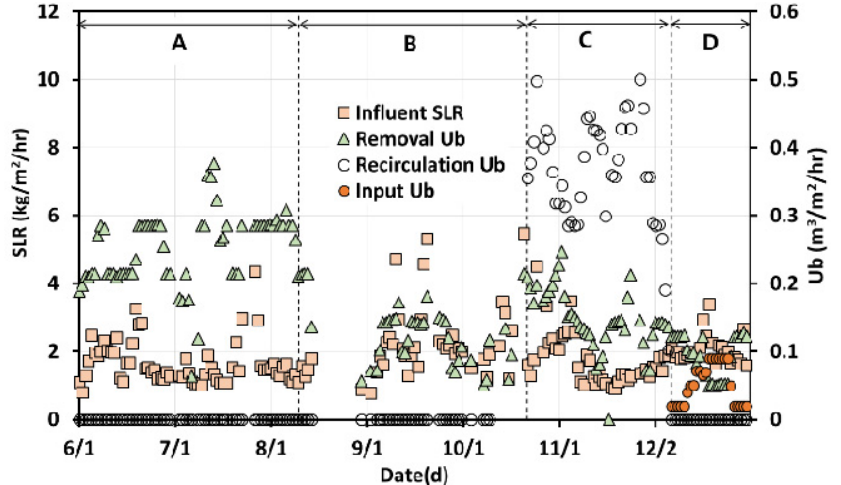

(a) Pilot 1

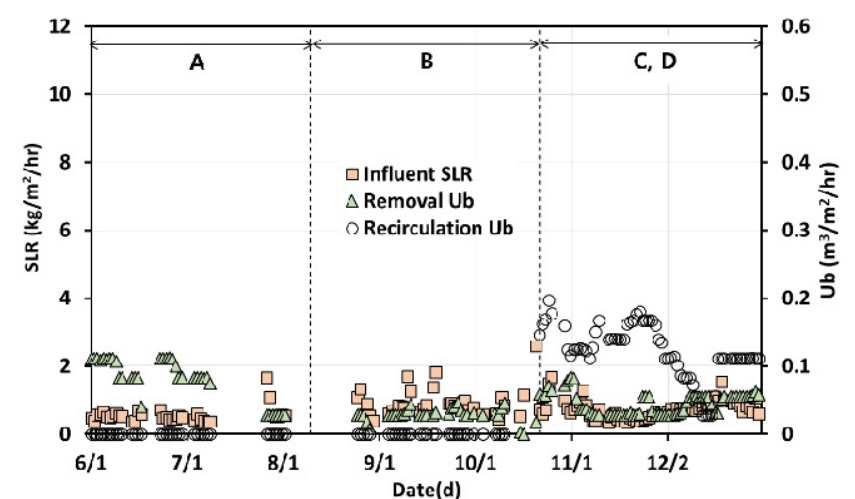

(b) Pilot 2

Fig.6. Influent solids loading rate and primary sludge underflow rate in pilot plant.

유입 SS $1 \sim 6 \mathrm{~g} / \mathrm{L}$ 에서 파일럿 1은 월류율 $0.8 \mathrm{~m} / \mathrm{hr}$, 일차 슬러지 제거 하부배출속도 $0.044 \sim 0.367 \mathrm{~m} / \mathrm{hr}$ 이었고, 파일 럿 2는 월류율 $0.3 \mathrm{~m} / \mathrm{hr}$, 제거 하부배출속도는 $0.016 \sim 0.135$ $\mathrm{m} / \mathrm{hr}$ 이었다(Fig.5). 파일럿 1, 2의 유입유량 대비 슬러지 제 거량(제거 하부배출속도/월류율) 비는 유입 SS $2 \mathrm{~g} / \mathrm{L}$ 에서 $0.11,0.11$ 이고 유입 SS $6 \mathrm{~g} / \mathrm{L}$ 에서 $0.46,0.45$ 이었다. 파일럿 1,2 의 용량차이가 슬러지 제거량 비에 주는 영향은 작았다. 유입 SS가 증가할수록 제거 하부배출속도는 증가하였다.

파일럿 1 에서 일차슬러지 재순환 하부배출속도를 0.36 $\mathrm{m} / \mathrm{hr}$ 으로 운전하면 제거 하부배출속도는 $0.05 \sim 0.53 \mathrm{~m} / \mathrm{hr}$ 이 고, 파일럿 2에서 일차슬러지 재순환 하부배출속도를 0.12 $\mathrm{m} / \mathrm{hr}$ 로 운전하면 제거 하부배출속도는 $0.02 \sim 0.19 \mathrm{~m} / \mathrm{hr}$ 이었 다. 재순환 운전일 때 파일럿 1,2 의 유입유량 대비 슬러지 제거량 비는 유입 SS $2 \mathrm{~g} / \mathrm{L}$ 에서 $0.16,0.15$ 이고 유입 SS 6 $\mathrm{g} / \mathrm{L}$ 에서는 $0.66,0.63$ 이었다. 재순환 운전에서 파일럿 1,2 의 용량차이로 인한 슬러지 제거량 비가 0.03 차이가 있었다. 재순환으로 유입 SS $2 \mathrm{~g} / \mathrm{L}$ 에서는 슬러지 제거량 비가 0.04 $\sim 0.05$ 증가하였고, 유입 SS $6 \mathrm{~g} / \mathrm{L}$ 에서 $0.18 \sim 0.20$ 증가하 여, SS가 증가할수록 재순환에 의한 슬러지 제거량 비는 증 가하였다.

\section{2. 고형물 부하율 기반 일차슬러지 제어기술 성능평가}

\subsection{1. 일차슬러지 하부배출속도 비교}

A기간 파일럿 1, 2의 유입 SLR $1.66 \mathrm{~kg} / \mathrm{m}^{2} / \mathrm{hr}, 0.56 \mathrm{~kg} / \mathrm{m}^{2} / \mathrm{hr}$ 에서 제거 하부배출속도는 $0.25 \mathrm{~m} / \mathrm{hr}, 0.08 \mathrm{~m} / \mathrm{hr}$ 로 나타나, 계산된 제거 하부배출속도 $0.09 \mathrm{~m} / \mathrm{hr}, 0.03 \mathrm{~m} / \mathrm{hr}$ 보다는 2.6 배 정도 높게 운전하였다(Fig.5,6). B기간 파일럿 1, 2의 제 거 하부배출속도는 $0.13 \mathrm{~m} / \mathrm{hr}, 0.03 \mathrm{~m} / \mathrm{hr}$ 으로 계산된 제거 하부배출속도보다 1.1 배, 1.7 배 높게 운전되었다. 실제로 고 형물 부하율을 기반으로 운전하는 자동인발은 수동인발 운 전보다 하부배출속도(슬러지 제거량)를 $48 \%, 63 \%$ 줄일 수 있었다. 파일럿 1 의 $\mathrm{C}$ 와 파일럿 2 의 $\mathrm{C}+\mathrm{D}$ 기간 제거 하부배 출속도는 $0.15 \mathrm{~m} / \mathrm{hr}, 0.04 \mathrm{~m} / \mathrm{hr}$ 로 계산된 제거 하부배출속도 보다 0.9 배, 1.5 배로 운전되었다. 자동인발+재순환 운전은 자동인발 운전보다 제거 하부배출속도가 $0.01 \sim 0.02 \mathrm{~m} / \mathrm{hr}$ 높았다. 파일럿 1 의 $\mathrm{D}$ 에서는 제거와 투입을 더한 전체적으 로 제거된 하부배출속도는 $0.14 \mathrm{~m} / \mathrm{hr}$ 이었고, 계산된 제거 하부배출속도와 비교하여 0.9 배 정도로 운전되었다. 종합적 으로 자동인발이 포함된 운전은 상태점 분석으로 계산된 하 부배출속도와 $0.9 \sim 1.7$ 배 차이가 있었고 수동인발 운전과 비교하여 하부배출속도를 정밀하게 제어할 수 있었다. 


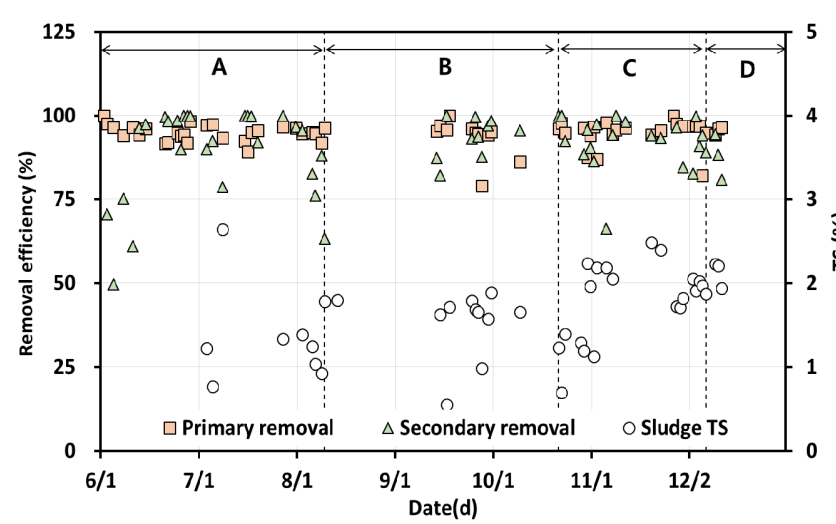

(a) Pilot 1

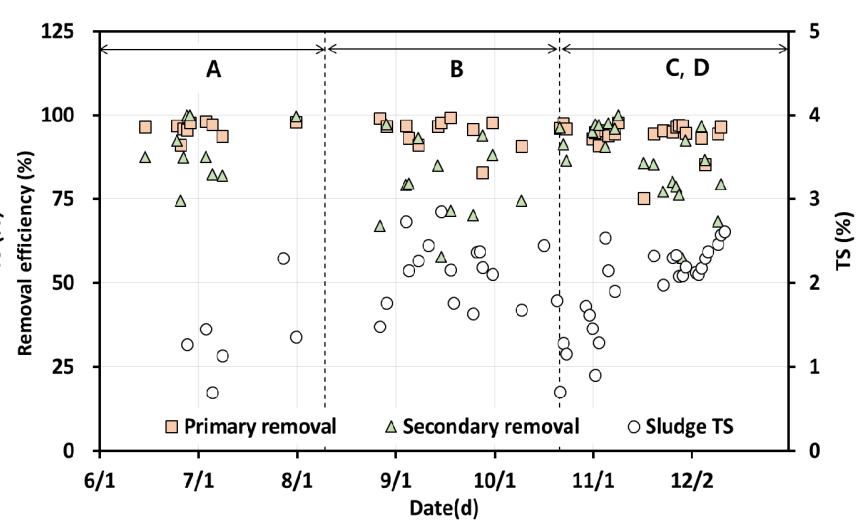

(b) Pilot 2

Fig.7. SS removal efficiency and primary sludge concentration by experimental conditions.

\subsection{2. 성능평가 결과}

파일럿 1,2 의 일차제거효율은 $\mathrm{A}$ 에서 $94.7 \%, 96.0 \%$ 이고 B에서 $93.6 \%, 94.7 \%$ 이었다(Fig.7(a)). 파일럿 1의 C와 파일 럿 2의 $\mathrm{C}+\mathrm{D}$ 에서 $\mathrm{SS}$ 일차제거효율은 $94.7 \%, 93.7 \%$ 이고 파 일럿 1 의 $\mathrm{D}$ 에서는 $95.3 \%$ 이었다. 각 운전기간별로 제거효율 차이는 $2.4 \%$ 이내로 자동인발과 재순환 운전으로 $\mathrm{SS}$ 일차 제거효율을 떨어트리지 않는 것으로 판단된다. 다만 파일럿 1 의 자동인발+재순환 운전에서 유입 고형물 부하율 $2.4 \mathrm{~kg} / \mathrm{m}^{2} / \mathrm{hr}$ 를 넘는 경우가 7회 발생하였고, 슬러지 계면이 상승하여 운 전에 어려움이 발생하였다. 파일럿 1,2 의 SS 이차제거효율 은 $\mathrm{A}$ 에서 $89.5 \%, 89.2 \%$ 이고 $\mathrm{B}$ 에서는 $90.7 \%, 79.7 \%$ 이었고, 파일럿 1 의 $\mathrm{C}$ 와 파일럿 2 의 $\mathrm{C}+\mathrm{D}$ 에서는 $92.2 \%, 86.8 \%$ 이 었다. 수동인발과 비교하여 자동인발이 포함된 운전에서 SS 이차제거효율이 파일럿 1 에서는 증가하고 파일럿 2에서는 감소하여 생물반응조의 운전조건과 관련이 있는 것으로 판단 된다.

파일럿 1 의 $\mathrm{A}$ 와 비교하여 $\mathrm{B}, \mathrm{C}, \mathrm{D}$ 는 일차슬러지 농도가 $2.4 \sim 7.4 \mathrm{~g} / \mathrm{L}$ 높았고, 파일럿 2 의 $\mathrm{A}$ 와 비교한 $\mathrm{B}, \mathrm{C}+\mathrm{D}$ 는 일 차슬러지 농도가 $5.8 \sim 7.6 \mathrm{~g} / \mathrm{L}$ 높았기 때문에 수동인발보다 는 자동인발이 포함된 운전에서 더 높은 농도의 슬러지를 제거할 수 있었다(Fig. 7(b)). 상태점 분석에서 목표 일차슬 러지 농도를 $19 \mathrm{~g} / \mathrm{L}$ 로 하였는데, 재순환과 투입 운전에서 목표 농도에 근접할 수 있었다. $\mathrm{C}$ 에서 전체 인발시간 5.8 분 중 각각 $0.17 \sim 4$ 분 경과하였을 때 침전슬러지 농도는 파일 럿 1 에서 $5.3 \mathrm{~g} / \mathrm{L}$ 감소하였고 파일럿 2 는 $1.1 \mathrm{~g} / \mathrm{L}$ 감소하여, 일차침전지 용량이 2.5 배 큰 파일럿 2 에서 인발시간에 따른 슬러지 농도 변화가 작았다(Fig. 8). 슬러지 재순환은 인발시 간이 길어지게 되는데 고농도의 슬러지를 제거하고 재순환 하기 위해서는 슬러지를 저장하는 일차침전지 최소용량확 보가 필요한 것으로 판단된다. 파일럿 2 의 경우 일차침전지 설계용량 대비 유입유량을 실플랜트보다 2 배 높게 설정하 였지만 재순환을 위해 필요한 슬러지를 저장하는 일차침전 지 최소용량이 확보된 것으로 나타났다.

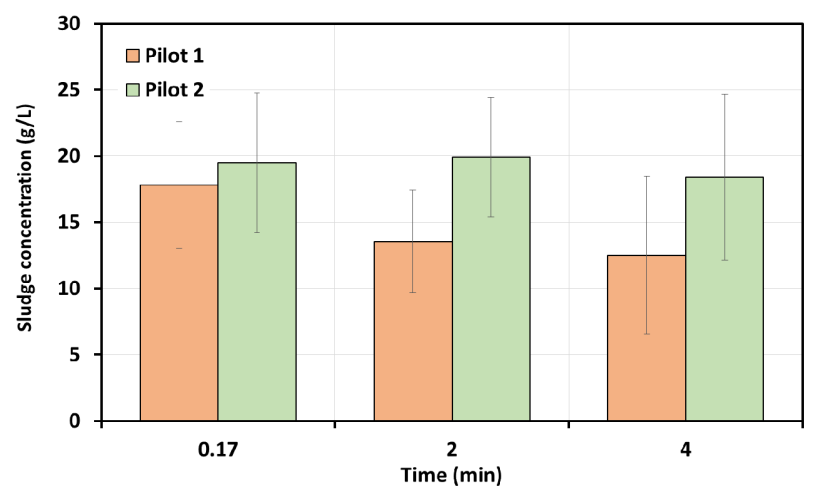

Fig. 8. Concentration of primary sludge according to the withdrawal time under the recirculation operation conditions.

수동인발 운전의 경우 유입 고형물 부하율의 최대값을 기 준으로 슬러지 인발량을 결정할 수밖에 없어 실제 운영에서 는 저농도 슬러지를 인발할 가능성이 높다. 유입 고형물 부 하율 변화에 따라서 슬러지 인발량을 조절하는 자동인발은 고농도 슬러지를 안정적으로 인발할 수 있으며, SS 제거효 율도 안정적으로 유지할 수 있었다. 자동인발+재순환, 자동 인발+투입 운전기간에도 고농도 슬러지 인발과 SS 제거효 율을 안정적으로 유지할 수 있었다. 파일럿 1, 2에서 운전 된 체류시간을 실플랜트보다 5.3 배, 2 배 낮게 운전하여도 자동인발로 안정적인 운전이 가능하여 실플랜트 처리용량 을 2 배 이상 증가할 수 있는 것으로 나타났다. 재순환 운전 에서 파일럿 1은 유입 고형물 부하율 $2.4 \mathrm{~kg} / \mathrm{m}^{2} / \mathrm{hr}$ 을 벗어나 면 운전에 어려움이 발생하였지만 파일럿 2 는 안정적으로 운전할 수 있었다. 또한 파일럿 2는 재순환을 위해 필요한 슬러지를 저장하는 일차침전지 최소용량이 확보되었다. 종 합적으로 슬러지 재순환 운전에서도 유입 고형물 부하율 변 화에 일차슬러지 하부배출속도를 제어하면 실플랜트에서 일 차침전지 처리용량을 2 배 이상 증가할 수 있을 것으로 판단 된다. 
Table 5. Primary effluent characteristics in pilot plants by experiment period.

\begin{tabular}{|c|c|c|c|c|c|c|c|}
\hline Pilot & Classification & $\begin{array}{l}\text { Ammonia } \\
\text { nitrogen }\end{array}$ & $\begin{array}{l}\text { Total inorganic } \\
\text { nitrogen (TIN) }\end{array}$ & $\begin{array}{c}\text { Phosphate } \\
\text { phosphorus }\left(\mathrm{PO}_{4}-\mathrm{P}\right)\end{array}$ & $\begin{array}{l}\text { Acetic acid } \\
\text { (AcOH) }\end{array}$ & $\begin{array}{l}\mathrm{AcOH} / \\
\mathrm{TIN}\end{array}$ & $\begin{array}{l}\mathrm{AcOH} / \\
\mathrm{PO}_{4}-\mathrm{P}\end{array}$ \\
\hline \multirow{3}{*}{1} & C & $\begin{array}{c}142.7 \\
(116.9-177.8)\end{array}$ & $\begin{array}{c}144.5 \\
(117.3-179.3)\end{array}$ & $\begin{array}{c}4.01 \\
(2.35-5.71)\end{array}$ & $\begin{array}{c}349.6 \\
(21.6-749.3)\end{array}$ & $\begin{array}{c}2.3 \\
(0.1-4.5)\end{array}$ & $\begin{array}{c}86.5 \\
(5.8-164.1)\end{array}$ \\
\hline & $\mathrm{D}$ & $\begin{array}{c}167.0 \\
(148.4-188.2)\end{array}$ & $\begin{array}{c}167.3 \\
(148.6-188.2)\end{array}$ & $\begin{array}{c}4.80 \\
(3.13-7.14)\end{array}$ & $\begin{array}{c}242.1 \\
(37.5-548.0)\end{array}$ & $\begin{array}{c}1.4 \\
(0.2-3.2)\end{array}$ & $\begin{array}{c}51.4 \\
(6.8-133.5)\end{array}$ \\
\hline & $E$ & $\begin{array}{c}175.7 \\
(156.3-223.3) \\
\end{array}$ & $\begin{array}{c}180.3 \\
(159.9-229.6) \\
\end{array}$ & $\begin{array}{c}3.78 \\
(2.80-5.46) \\
\end{array}$ & $\begin{array}{c}68.9 \\
(0.5-272.5) \\
\end{array}$ & $\begin{array}{c}0.4 \\
(0.0-1.7) \\
\end{array}$ & $\begin{array}{c}18.0 \\
(0.2-71.3) \\
\end{array}$ \\
\hline \multirow{3}{*}{2} & C & $\begin{array}{c}150.7 \\
(113.0-202.3) \\
\end{array}$ & $\begin{array}{c}151.0 \\
(113.1-102.4) \\
\end{array}$ & $\begin{array}{c}4.41 \\
(2.98-6.70) \\
\end{array}$ & $\begin{array}{c}434.3 \\
(110.1-783.6) \\
\end{array}$ & $\begin{array}{c}2.8 \\
(0.8-6.1) \\
\end{array}$ & $\begin{array}{c}100.8 \\
(27.7-234.6) \\
\end{array}$ \\
\hline & $\mathrm{D}$ & $\begin{array}{c}168.0 \\
(152.9-184.4)\end{array}$ & $\begin{array}{c}168.1 \\
(153.2-184.4)\end{array}$ & $\begin{array}{c}5.43 \\
(4.14-6.69)\end{array}$ & $\begin{array}{c}407.2 \\
(158.1-637.3)\end{array}$ & $\begin{array}{c}2.4 \\
(1.0-3.9)\end{array}$ & $\begin{array}{c}79.7 \\
(23.6-153.9)\end{array}$ \\
\hline & $\mathrm{E}$ & $\begin{array}{c}157.4 \\
(147.2-162.6)\end{array}$ & $\begin{array}{c}158.8 \\
(148.6-164.1)\end{array}$ & $\begin{array}{c}2.95 \\
(2.56-3.37)\end{array}$ & $\begin{array}{c}154.5 \\
(1.0-301.5)\end{array}$ & $\begin{array}{c}1.0 \\
(0.0-2.0)\end{array}$ & $\begin{array}{c}55.3 \\
(0.3-117.8)\end{array}$ \\
\hline
\end{tabular}

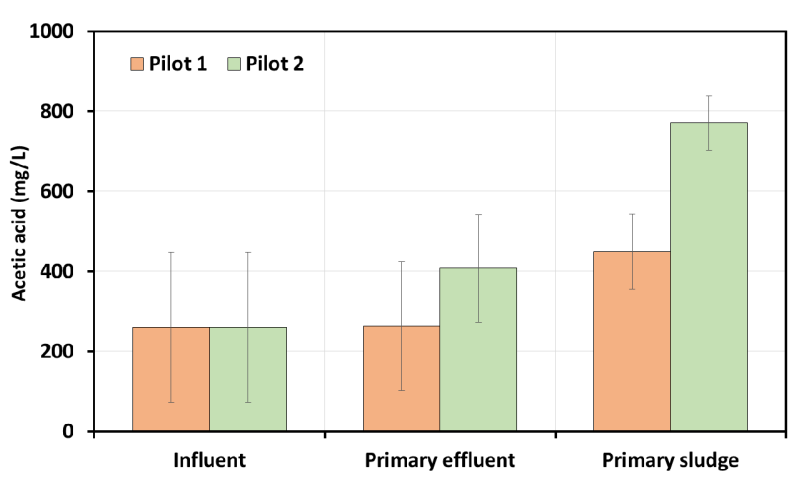

Fig.9. Acetic acid concentration of influent, primary effluent and primary sludge in sludge recirculation stage.

\section{3. 일차슬러지 재순환/투입에 의한 생물반응조 질소, 인 제거효율 변화}

\subsection{1. 일차처리수 성상의 변화}

파일럿 1 의 $\mathrm{C}$ 와 파일럿 2 의 $\mathrm{C}, \mathrm{D}$ 는 재순환 조건이고 파일 럿 1 의 $\mathrm{D}, \mathrm{E}$ 와 파일럿 2 의 $\mathrm{E}$ 는 재순환이 없는 조건으로 서로 비교하여 일차처리수 성상 변화를 확인하였다. 파일럿 1,2 의 $\mathrm{C}, \mathrm{D}, \mathrm{E}$ 에서 암모니아성질소, 총무기질소, 인산염인의 농도 변화보다 아세트산 $68.9 \sim 434.3 \mathrm{mg} / \mathrm{L}$ 의 농도 변화가 커서 $\mathrm{AcOH} / \mathrm{TIN}$ (아세트산/총무기질소) 비, $\mathrm{AcOH} / \mathrm{PO}_{4}-\mathrm{P}$ (아세트산/ 인산염인) 비는 아세트산에 의해 주로 결정되었다(Table 5). 재순환이 있는 $\mathrm{C}$ 와 재순환이 없는 $\mathrm{E}$ 의 $\mathrm{AcOH} / \mathrm{TIN}$ 비는 파일 럿 1이 파일럿 2보다 $0.5 \sim 0.6$ 높았는데 일차침전지 체류시 간이 긴 파일럿 2에서 미생물 분해가 더 일어났고 아세트산 을 $84.7 \sim 85.6 \mathrm{mg} / \mathrm{L}$ 더 많이 생성한 결과로 보여진다. 이 값과 파일럿 1 의 $\mathrm{D}$ 에 해당하는 값을 더하면 파일럿 2 의 $\mathrm{D}$ 에서 재 순환이 없는 상태의 아세트산과 $\mathrm{AcOH} / \mathrm{TIN}$ 비를 $326.8 \mathrm{mg} / \mathrm{L}$, 1.9 로 계산할 수 있고, 재순환으로 $80.4 \mathrm{mg} / \mathrm{L}, 0.5$ 가 증가되 었다고 추정할 수 있다. 종합하면 파일럿 1 과 비교하여 파 일럿 2의 $\mathrm{D}$ 는 아세트산 농도를 재순환함으로써 $19.7 \%$, 일 차침전지 체류시간이 더 길어짐으로써 $20.8 \%$ 를 더 생산이 가능한 것으로 나타났다. 파일럿 1 의 $\mathrm{D}$ 는 투입운전으로 재
순환이 중단되는 것을 의미하며 C와 $\mathrm{D}$ 를 비교하면 재순환으 로 아세트산과 $\mathrm{AcOH} / \mathrm{TIN}$ 비가 $107.5 \mathrm{mg} / \mathrm{L}, 0.9$ 증가한 것 을 알 수 있다. D에서 재순환으로 아세트산 농도와 $\mathrm{AcOH} / \mathrm{TIN}$ 비는 $80.4 \sim 107.5 \mathrm{mg} / \mathrm{L}, 0.5 \sim 0.9$ 증가한 것으로 사료된다. $\mathrm{AcOH} / \mathrm{PO}_{4}-\mathrm{P}$ 비도 $\mathrm{AcOH} / \mathrm{TIN}$ 비와 유사한 경향을 보였다.

$\mathrm{D}$ 에서 파일럿 1 은 유입수, 일차처리수, 일차슬러지의 아 세트산 농도가 $259.4 \mathrm{mg} / \mathrm{L}, 263.2 \mathrm{mg} / \mathrm{L}, 449.4 \mathrm{mg} / \mathrm{L}$ 이고 파일 럿 2는 $259.4 \mathrm{mg} / \mathrm{L}, 407.2 \mathrm{mg} / \mathrm{L}, 770.7 \mathrm{mg} / \mathrm{L}$ 이었다(Fig. 9). 체류시간이 길고 재순환이 있는 파일럿 2 가 재순환이 없이 투입운전 한 파일럿 1 보다 일차처리수와 일차슬러지의 아 세트산 농도가 $144.0 \mathrm{mg} / \mathrm{L}, 321.3 \mathrm{mg} / \mathrm{L}$ 높아서 미생물에 의 한 분해가 파일럿 2 에서 더 진행된 것으로 보인다. 파일럿 2 에서 일차슬러지의 아세트산 농도는 유입수보다 2.9 배 높 았고, 일차처리수는 유입수보다 1.56 배 높아 일차슬러지 순 환을 통해 아세트산 일부가 일차처리수로 이동한 것으로 판 단된다. Jin 등 ${ }^{36}$ 은 하수를 대상으로 일차슬러지 재순환을 통해 VFAs $12.1 \mathrm{mg} / \mathrm{L}$ 증가하였고, 일차슬러지와 유입수를 기계적으로 교반하여 VFAs $21.7 \mathrm{mg} / \mathrm{L}$ 증가시켰다고 하였 다. Shi 등 ${ }^{38}$ 은 활성 일차침전지(APST)에 배플을 설치하여 VFAs $4.49 \mathrm{mg} / \mathrm{L}$ 가 증가되었다고 보고하였다. 슬러지 소화 공정에서 발생하는 반류수는 VFAs 농도는 높기 때문에 유 입 반류수의 VFAs 농도는 기본적으로 높은 수준이며, 재순 환 시 일차슬러지는 침전지에서 추가적으로 분해되어 VFAs 농도 증대에 기여하는 것으로 확인되었다. 또한 재순환에 의한 일차슬러지와 유입수의 접촉은 일차처리수의 VFAs 농 도를 상승시키는 원인으로 파악되었다. 일차슬러지 아세트 산 농도 $449.4 \mathrm{mg} / \mathrm{L}, 770.7 \mathrm{mg} / \mathrm{L}$ 를 고려하면 생물반응조 투 입으로 증가하는 아세트산 농도는 $12 \sim 38 \mathrm{mg} / \mathrm{L}$ 로 계산되 어 생물반응조에 일차슬러지 투입은 아세트산이 투입되는 것을 의미하였다.

\subsection{2. 생물반응조 질소, 인 제거효율 변화}

파일럿 1 의 $\mathrm{C}, \mathrm{D}$ 에서 생물반응조 $\mathrm{TIN}$ 제거효율은 $\mathrm{E}$ 와 비 
Table 6. Bioreactor nitrogen and phosphorus removal efficiency in pilot plant by experiment period.

\begin{tabular}{|c|c|c|c|c|c|c|}
\hline \multirow[b]{2}{*}{ Pilot } & \multirow[b]{2}{*}{ Classification } & \multicolumn{3}{|c|}{ Removal efficiency (\%) } & \multicolumn{2}{|c|}{ Rate (g-N/g-MLSS/d) } \\
\hline & & $\begin{array}{l}\text { Ammonia } \\
\text { nitrogen }\end{array}$ & $\begin{array}{l}\text { Total inorganic } \\
\text { nitrogen (TIN) }\end{array}$ & $\begin{array}{l}\text { Phosphate } \\
\text { phosphorus }\end{array}$ & SNR & SDNR \\
\hline \multirow[t]{2}{*}{1} & $\mathrm{D}$ & $\begin{array}{c}59.3 \\
(52.6-65.1) \\
\end{array}$ & $\begin{array}{c}34.3 \\
(23.5-40.8) \\
\end{array}$ & $\begin{array}{c}72.0 \\
(59.8-88.6)\end{array}$ & $\begin{array}{c}0.093 \\
(0.080-0.115)\end{array}$ & $\begin{array}{c}0.162 \\
(0.097-0.220)\end{array}$ \\
\hline & $E$ & $\begin{array}{c}60.6 \\
(50.7-72.2)\end{array}$ & $\begin{array}{c}23.1 \\
(13.2-31.0)\end{array}$ & $\begin{array}{c}71.8 \\
(63.9-77.2) \\
\end{array}$ & $\begin{array}{c}0.027 \\
(0.003-0.040)\end{array}$ & $\begin{array}{c}0.027 \\
(0.006-0.041)\end{array}$ \\
\hline \multirow{3}{*}{2} & C & $\begin{array}{c}69.4 \\
(50.4-83.1) \\
\end{array}$ & $\begin{array}{c}28.3 \\
(11.6-53.9) \\
\end{array}$ & $\begin{array}{c}64.3 \\
(17.5-100.0) \\
\end{array}$ & $\begin{array}{c}0.121 \\
(0.021-0.245)\end{array}$ & $\begin{array}{c}0.139 \\
(0.032-0.286)\end{array}$ \\
\hline & D & $\begin{array}{c}72.1 \\
(54.4-80.0)\end{array}$ & $\begin{array}{c}40.3 \\
(26.5-59.8) \\
\end{array}$ & $\begin{array}{c}72.6 \\
(50.7-88.6) \\
\end{array}$ & $\begin{array}{c}0.037 \\
(0.024-0.076)\end{array}$ & $\begin{array}{c}0.061 \\
(0.029-0.105)\end{array}$ \\
\hline & $E$ & $\begin{array}{c}54.7 \\
(50.2-58.9)\end{array}$ & $\begin{array}{c}19.2 \\
(12.0-29.7)\end{array}$ & $\begin{array}{c}58.0 \\
(52.2-69.1)\end{array}$ & $\begin{array}{c}0.032 \\
(0.003-0.049)\end{array}$ & $\begin{array}{c}0.025 \\
(0.006-0.036)\end{array}$ \\
\hline
\end{tabular}

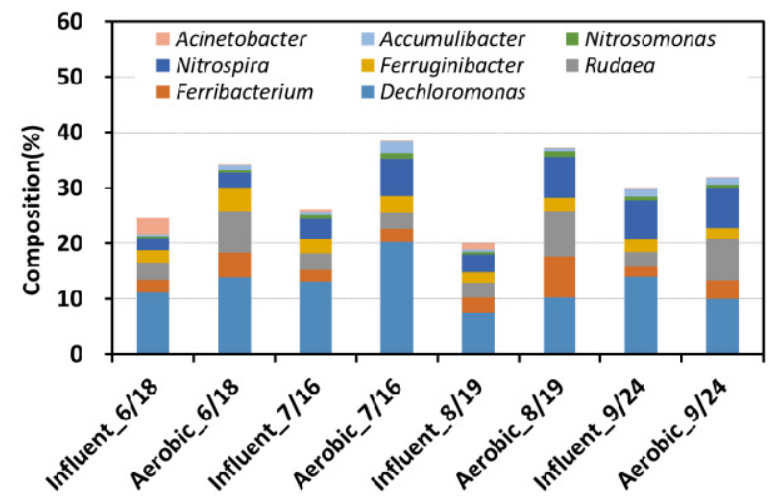

(a) Major microorganisms related to pollutant removal

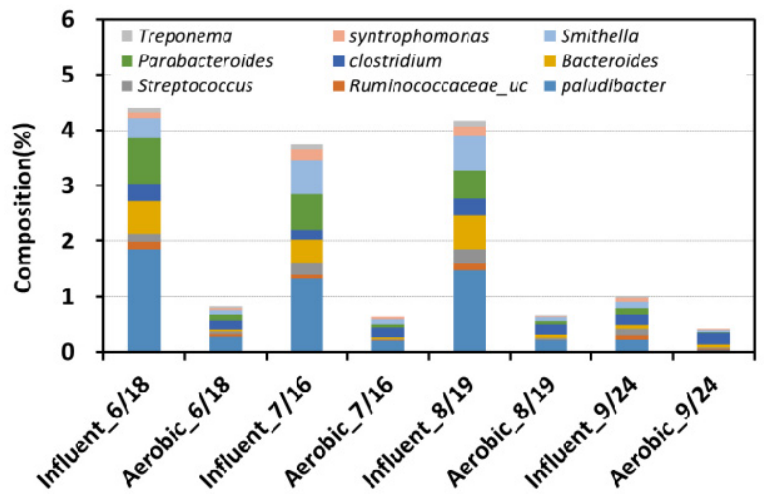

(b) Sludge fermentation microorganism

Fig. 10. Analysis of the microbial community of influent and aeration tank in the full-scale MLE process.

교하여 재순환과 투입으로 $24.2 \%, 32.6 \%$ 향상되었고, SDNR 을 비교하여도 $\mathrm{C}, \mathrm{D}$ 는 $\mathrm{E}$ 보다 4.7 배, 6.0 배 높아 질소제거효 율이 향상되었음을 확인할 수 있었다(Table6). 인산염인 제 거효율에 있어서는 $\mathrm{C}$ 는 $\mathrm{E}$ 보다 $8.7 \%$ 감소하였고 $\mathrm{D}$ 와는 비 슷하여 재순환과 투입에 의한 효과는 나타나지 않았다. D 는 $\mathrm{C}$ 보다 $\mathrm{AcOH} / \mathrm{TIN}$ 비가 0.9 낮았는데도 $\mathrm{TIN}$ 제거효율과 $\mathrm{SDNR}$ 이 높았고, $\mathrm{D}$ 는 $\mathrm{E}$ 보다 낮은 MLSS $2,597 \mathrm{mg} / \mathrm{L}$ 에서도 $\mathrm{TIN}$ 제거효율과 SDNR이 높았다. 이를 통해 일차슬러지 투 입이 질소 제거효율을 높여 주는 것으로 나타났다.

파일럿 2의 생물반응조 $\mathrm{TIN}$ 제거효율은 $\mathrm{C}, \mathrm{D}$ 를 $\mathrm{E}$ 와 비교 하였을 때 재순환으로 $32.1 \%, 52.3 \%$ 향상되었고, SDNR을 비교하면 $\mathrm{C}, \mathrm{D}$ 는 $\mathrm{E}$ 보다 5.5배, 2.4배 높아 재순환으로 질소 제거효율이 향상되었음을 확인할 수 있었다. 인산염인 제거 효율은 재순환 효과에 의해 인 제거효율이 최대 $20.1 \%$ 향 상되었다. $\mathrm{D}$ 는 $\mathrm{C}$ 보다 $\mathrm{TIN}$ 제거효율이 높은데 반해 $\mathrm{SNR}$ 과 $\mathrm{SDNR}$ 은 낮았는데, 이는 $\mathrm{D}$ 의 MLSS가 $8,187 \mathrm{mg} / \mathrm{L}$ 로 $\mathrm{C}$ 보다 2.9 배 높게 운전되었기 때문이며, $\mathrm{D}$ 는 반응온도가 낮았는데 도 재순환으로 $\mathrm{AcOH} / \mathrm{TIN}$ 비가 2.4로 유지되어 생물반응조 에서 TIN 제거효율이 향상된 것으로 나타났다. 일차슬러지
재순환으로 생물반응조의 질소, 인 제거효율을 향상시키는 것으로 판단하였다.

\subsection{3. 유입 반류수와 호기조 미생물 군집 분석}

유입 반류수와 실플랜트 호기조의 미생물 군집 분석결과, 탈질 관련 미생물 Dechloromonas, 질산화 관련 미생물 Nitrospira, Nitrosomonas, 인 제거 관련 미생물 Acinetobacter, Accumulibacter, 종속영양균 Ferruginibacter, 셀룰로오스 분해 균 Rudaea, 철환원균 Ferribacterium 등이 주요 종으로 분포하 였다(Fig. 10). 주요 미생물 군집 비율은 유입수, 호기조에서 $25.1 \%, 35.4 \%$ 이었고, Dechloromonas는 유입수와 호기조에서 군집비율이 각각 $11.4 \%, 13.5 \%$ 로 가장 높게 존재하였다. 유입 반류수에는 호기조에 있는 질소, 인 등을 제거하는 미생물 군집이 상당히 존재하고 있었다. 유입 반류수는 슬러 지 농축, 소화, 탈수 공정에서 발생하는 여액으로 하수처리 공정(Mainstream) 미생물이 유입되고, 일차처리 반류수에 포 함된 미생물은 반류수처리공정(Sidestream) 생물반응조로 유 입되는 것으로 판단된다. 이에 유입 반류수에는 다양한 종류의 미생물을 포함하고 있고, 호기조의 미생물과 유사한 군집을 
구성하는 것으로 나타났다. 인 제거와 관련한 Acinetobacter는 유입수와 호기조에 각각 $1.10 \%, 0.06 \%$ 존재하여 유입수에 더 많이 존재하였다. 일차슬러지를 생물반응조에 투입하는 것은 질소, 인 등을 제거하는 미생물을 공급하여 제거효율을 향상시 키는 하나의 원인이 될 수 있는 것으로 사료된다. 슬러지 발효와 관련된 미생물 주요 종은 Paludibacter, Ruminococcaceae_uc, Streptococcus, Bacteroides, Clostridium, Parabacteroides, Smithella, Syntrophomonas, Treponema 등 이었다. 발효 미생물 주요 종 비율은 유입수와 호기조에서 $2.1 \%, 0.5 \%$ 로 유입수가 높았다. 유입수에서 Paludibacter, Bacteroides, Parabacteroides, Smithella가 $0.4 \%$ 이상 존재하였다. 발효 미생물의 높은 비율 은 일차슬러지 재순환에서 아세트산 생성을 촉진할 수 있는 원인으로 판단된다.

\section{4. 결 론}

유입 고형물 부하율을 모니터링하고 고형물 플럭스와 상 태점 분석을 통해 일차슬러지 하부배출속도를 산정하여 슬 러지 제거, 재순환, 투입에 대한 제어기술을 개발하였고 일 차침전지의 성능평가, 생물반응조의 질소, 인 제거효율 및 원인분석을 수행하여 다음과 같은 결론을 도출하였다.

1) 유입 반류수 SS 모니터링 평균값은 $2.2(0.7 \sim 6.3) \mathrm{g} / \mathrm{L}$ 로 일차침전지는 고농도 $\mathrm{SS}$ 와 변동에 대응하여 처리하는 기능이 필요하였다. 파일럿 1 의 유입 고형물 부하율은 1.87 $(0.77 \sim 5.48) \mathrm{kg} / \mathrm{m}^{2} / \mathrm{hr}$ 로 이차침전지 고형물 부하율 설계기 준 최대값 $5.2 \mathrm{~kg} / \mathrm{m}^{2} / \mathrm{hr}$ 를 넘었으나 상태점 분석에서는 안정 적인 운전이 가능하였다. 일차슬러지 재순환 운전에서 상태 점 분석을 한 결과 파일럿 1 은 안정적 운전이 어렵고, 파일 럿 2는 안정적인 운전이 가능한 것으로 나타났다. 실제 침 강속도에 기반한 상태점 분석이 정밀하게 일차슬러지 제거, 재순환, 투입 운전에 대한 안정적인 운전 가능여부와 구체 적인 설계 및 운영기준을 제시할 수 있는 것으로 판단된다.

2) 자동인발 운전은 수동인발 운전보다 슬러지 제거량이 $48 \sim 63 \%$ 작았다. 자동인발이 포함된 운전의 제거 하부배출 속도는 $0.03 \sim 0.15 \mathrm{~m} / \mathrm{hr}$ 로 상태점 분석으로 계산된 하부배 출속도와 $0.9 \sim 1.7$ 배 차이가 있었으나 수동인발 운전보다 하부배출속도를 정밀하게 제어할 수 있었다. 운전기간별 SS 일차제거효율은 93.6 96.0\%이었고 자동인발과 재순환 운 전이 제거효율을 떨어트리지는 않았다. 수동인발에서 일차 슬러지 농도는 $13.2 \sim 13.7 \mathrm{~g} / \mathrm{L}$ 이고 자동인발에서는 15.6 $21.3 \mathrm{~g} / \mathrm{L}$ 로 자동인발을 통해 슬러지 농도를 최대 $8.1 \mathrm{~g} / \mathrm{L}$ 높 게 할 수 있었다. 유입 고형물 부하율 변화에 따라서 하부배 출속도를 제어하는 자동인발은 고농도 슬러지를 안정적으 로 인발할 수 있으며, SS 제거효율도 안정적으로 유지할 수 있었다.

3) 자동인발로 운전한 파일럿은 설계용량 대비 유입유량 을 실플랜트보다 2 5.3배 높게 운전하여도 안정적인 운전
이 가능하였다. 재순환 운전에서 파일럿 1 은 유입 고형물 부하율 $2.4 \mathrm{~kg} / \mathrm{m}^{2} / \mathrm{hr}$ 을 벗어나면 운전에 어려움이 발생하였 지만 파일럿 2 는 안정적으로 운전할 수 있었다. 파일럿 2는 재순환을 위해 필요한 슬러지를 저장하는 일차침전지 최소 용량이 확보된 것으로 판단되었다. 슬러지 재순환 운전에서 도 유입 고형물 부하율 변화에 일차슬러지 하부배출속도를 제어하면 실플랜트에서 일차침전지 처리용량을 2 배 이상 증가할 수 있는 것으로 판단된다.

4) 일차슬러지 재순환으로 생물반응조 총무기질소(TIN) 제거효율은 $24.2 \sim 52.3 \%$ 향상되었고, SDNR은 $2.4 \sim 4.7$ 배 높았으며 인산염인 제거효율에 있어서도 최대 $20.1 \%$ 향상 되었다. 일차슬러지 투입으로 생물반응조 TIN 제거효율이 $32.6 \%$ 향상되었고, SDNR은 6배 높았다. 재순환에 의한 미생 물 분해와 일차슬러지 접촉으로 아세트산이 $80.4 \sim 107.5 \mathrm{mg} / \mathrm{L}$ 생성되었고 $\mathrm{AcOH} / \mathrm{TIN}$ 이 $0.5 \sim 0.9$ 증가하였다. Paludibacter, Bacteroides 등 발효 미생물 주요 종 비율은 $2.0 \%$ 존재하여 아세트산 생성을 향상시키는 것으로 나타났다. 유입 반류수 에는 Dechloromonas, Nitrospira, Acinetobacter 등 질소, 인 처리 미생물 주요 종이 $26.4 \%$ 존재하며, 일차슬러지 투입으 로 미생물 및 아세트산 공급이 이루어져서 질소, 인 제거효 율을 향상시켰다고 판단된다.

\section{Acknowledgement}

본 연구는 2017년부터 2018년까지 서울물연구원 연구과 제로 수행되었습니다. 이에 감사드립니다.

\section{References}

1. Ministry of Environment (MOE) Republic of Korea, Statistics of Sewerage in 2018(2019).

2. Ministry of Environment (MOE) Republic of Korea, Operation Result Survey Table in 2018(2020).

3. Q. He, J. Zhou, Q. Song, W. Zhang, H. Wang, L. Liu, Elucidation of microbial characterization of aerobic granules in a sequencing batch reactor performing simultaneous nitrification, denitrification and phosphorus removal at varying carbon to phosphorus ratios, Bioresour. Technol., 241, 127-133(2017).

4. K. Jo, Y. Park, S. Cho, T. Lee, Variation of nitrogen removal efficiency and microbial communities depending on operating conditions of a CANON process, J. Korean Soc. Environ. Eng., 37(6), 332-339(2015).

5. H. G. Kim, D. H. Ahn, E. H. Cho, H. Y. Kim, H. Y. Ye, J. S. Mun, A study on the biological treatment of RO concentrate using aerobic granular sludge, J. Korean Soc. Environ. Eng., 38(2), 79-86(2016).

6. D. Choi, W. Yun, D. Ju, J. Jung, Effect of internal recycle ratio on nitrogen removal efficiency in a three-stage ANAMMOX process for treating reject water, J. Korean 
Soc. Environ. Eng., 42(5), 259-266(2020).

7. P. Lee, D. Lee, B. Kim, Y. Hwang, T. Lee, A study on the improvement of nitrogen \& phosphorus removal of a sequence batch reactor with internal circulation and multi-step addition, J. Korean Soc. Environ. Eng., 42(5), 280-288(2020).

8. R. Tchobanoglous, G. T. Stensel, H. D. Burton, F. L. Tsuchihashi, Wastewater Engineering: Treatment and Resource Recovery, 5th ed., McGraw Hill, New York, USA(2015).

9. Ministry of Environment (MOE) Republic of Korea, Design Criteria of Wastewater Treatment(2011).

10. B. F. Severin, Clarifier sludge-blanket behavior at industrial activated-sludge plant, J. Environ. Eng., 117(6), 718-730(1991).

11. N. Raggul, R. Saraswathi, Design and development of operational diagram for controlling the performance of activated sludge process with a case study, J. Environ. Eng., 142(6), 1-13(2016).

12. H. Gao, M. K. Stenstrom, Evaluating the effects of inlet geometry on the limiting flux of secondary settling tanks with CFD model and 1D flux theory model, J. Environ. Eng., 145(10), 1-9(2019).

13. D. S. Parker, D. J. Kinnear, E. J. Wahlberg, Review of folklore in design and operation of secondary clarifiers, J. Environ. Eng., 127(6), 476-484(2001).

14. E. J. La Motta, J. A. Rojas, J. A. McCorquodale, Using the kinetics of biological flocculation and the limiting flux theory for the preliminary design of activated sludge systems. II: experimental verification, J. Environ. Eng., 133(1), 111-116(2007).

15. D. Rhu, E. Choi, Evaluation of solids loading rates concerned with activated sludge settling characteristics in secondary clarifier, J. Korean Soc. Civ. Eng., 20(4B), 599-605(2020).

16. T. M. Keinath, Operational dynamics and control of secondary clarifiers, J. Water Pollut. Control Fed., 57(7), 770-776(1985).

17. T. M. Keinath, M. D. Ryckman, C. H. Dana, D. A. Hofer, Activated sludge-unified system design and operation, J. Environ. Eng., 103(5), 829-849(1977).

18. N. V. Tuyen, J. H. Ryu, H. G. Kim, D. H. Ahn, Anammox bacteria immobilization using polyvinyl alcohol/sodium alginate crosslinked with sodium sulfate, J. Environ. Eng., 146(4), 1-8(2020).

19. R. Bashar, K. G. Karthikeyan, Assessment of the potential for full-scale implementation of mainstream anaerobic wastewater treatment scheme, World Environ. Water Resour. Congr. 2017, 324-333(2017).

20. Z. Hu, D. Houweling, P. Dold, Biological nutrient removal in municipal wastewater treatment: new directions in sustainability, J. Environ. Eng., 138(3), 307-317(2012).

21. C. Chen, Y. Wang, Y. Jiang, M. Guo, M. Cui, T. C. Zhang, Effects of organic-matter-induced short-term stresses on performance and population dynamics of anammox systems, J. Environ. Eng., 146(10), 1-12(2020).

22. Y. Ji, C. Tan, D. Cui, Y. Liu, L. Jiang, Enhanced effects of tourmaline on moving bed biofilm reactor-based partial nitrification process, J. Environ. Eng., 145(4), 1-8(2019).

23. C. Tan, D. Cui, Y. Liu, Y. Ji, Influence of tourmaline on the anaerobic ammonium oxidation process in sequencing batch reactors, J. Environ. Eng., 143(9), 1-7(2017).

24. X. Mao, P. H. Myavagh, S. Lotfikatouli, B. S. Hsiao, H. W. Walker, Membrane bioreactors for nitrogen removal from wastewater: a review, J. Environ. Eng., 146(5), 1-19(2020).

25. Y. H. Ahn, R. E. Speece, Elutriated acid fermentation of municipal primary sludge, Water Res., 40(11), 2210-2220 (2006).

26. L. Zhang, S. Zhang, S. Wang, C. Wu, Y. Chen, Y. Wang, Y. Penga, Enhanced biological nutrient removal in a simultaneous fermentation, denitrification and phosphate removal reactor using primary sludge as internal carbon source, Chemosphere, 91(5), 635-640(2013).

27. R. Moser-Engeler, M. Kühni, C. Bernhard, H. Siegrist, Fermentation of raw sludge on an industrial scale and applications for elutriating its dissolved products and non-sedimentable solids, Water Res., 33(16), 3503-3511(1999).

28. Y. Yuan, J. Liu, B. Ma, Y. Liu, B. Wang, Y. Peng, Improving municipal wastewater nitrogen and phosphorous removal by feeding sludge fermentation products to sequencing batch reactor (SBR), Bioresour. Technol., 222, 326-334(2016).

29. Y. Li, L. Lin, X. Li, Chemically enhanced primary sedimentation and acidogenesis of organics in sludge for enhanced nitrogen removal in wastewater treatment, J. Clean. Prod., 244, 118705(2020).

30. W. Liu, H. Yang, J. Ye, J. Luo, Y. Li, J. Liu, Short-chain fatty acids recovery from sewage sludge via acidogenic fermentation as a carbon source for denitrification : a review, Bioresour. Technol., 311, 123446(2020).

31. L. Lin, R. Li, X. Li, Recovery of organic resources from sewage sludge of Al-enhanced primary sedimentation by alkali pretreatment and acidogenic fermentation, J. Clean. Prod., 172, 3334-3341(2018).

32. Q. Feng, Y. Song, S. Jang, Ferric chloride addition enhances performance of bioelectrochemical anaerobic digestion of sewage sludge at ambient temperature, J. Korean Soc. Environ. Eng., 38(11), 618-626(2016).

33. L. Lin, R. Li, Z. Yang, X. Li, Effect of coagulant on acidogenic fermentation of sludge from enhanced primary sedimentation for resource recovery : comparison between, Chem. Eng. J., 325, 681-689(2017).

34. H. Yang, J. Liu, P. Hu, L. Zou, Y. Li, Carbon source and phosphorus recovery from iron-enhanced primary sludge via anaerobic fermentation and sulfate reduction : performance and future application, Bioresour. Technol., 294, 122174(2019).

35. J. Chanona, J. Ribes, A. Seco, J. Ferrer, Optimum design and operation of primary sludge fermentation schemes for volatile fatty acids production, Water Res., 40(1), 53-60(2006).

36. P. Jin, X. Wang, Q. Zhang, X. Wang, H. Hao, L. Yang, A new activated primary tank developed for recovering carbon source and its application, Bioresour. Technol., 200, 722-730 
(2016)

37. X. Wang, P. Jin, A. Zhang, J. Gao, B. Zhang, Y. Hou, Effect of mechanical elutriation on carbon source recovery from primary sludge in a novel activated primary tank, Chemosphere, 240, 124820(2020).

38. X. Shi, Y. Yao, N. Zhao, X. Jin, P. Jin, X. Wang, G. Wang, Characteristics of flow regime adjustment enhancing carbon source recovery in activated primary sedimentation tank, Chemosphere, 251, 126405(2020).

39. A. Bouzas, J. Ribes, J. Ferrer, A. Seco, Fermentation and elutriation of primary sludge: effect of SRT on process performance, Water Res., 41(4), 747-756(2007).

40. WEF \& ASCE, Design of Municipal Wastewater Treatment Plants(1998).

41. P. A. Vesilind, Treatment and Disposal of Wastewater Sludges, Ann Arbor Science Publishers(1979).

\section{Authors}

\section{Shinyo Chang}

Seoul Waterworks Research Institute, Seoul Metropolitan Government, Researcher, ORCID (1) 0000-0003-0280-9420

\section{Pung Shik Shin}

Seoul Waterworks Research Institute, Seoul Metropolitan Government, Researcher, ORCID (0) 0000-0003-2437-8158

\section{Hyeon Park}

Seoul Waterworks Research Institute, Seoul Metropolitan Government, Director, ORCID (ㅇ) 0000-0001-5816-9720

\section{Yeon-Koo Jeong}

Department of Environmental Engineering, Kumoh National Institute of Technology, Professor, ORCID(D) 0000-0002-1612-8194 